\title{
Performans Değerlendirme Ve Ücret Uygulamalarına İlişkin Algının İş Tatmini Ve Örgütsel Bağlılığa Etkisi: Bir Uygulama
}

\author{
Mehmet Selim DÜZGÜN*
}

\author{
Akın MARŞAP**
}

\begin{abstract}
ÖZ
Araştırma, İstanbul'da faaliyet gösteren 5 yıldızlı oteller üzerinde yapılmıştır. Araştırmada performans ve ücret uygulamalarının iş tatmini, örgütsel bağlllık ve alt boyutları ile ilişkileri incelenmistir. Bu araştırmada, performans ve ücret uygulamalarına ilişkin algının örgütsel bağlllı̆̆ ve iş tatminini pozitif etkilediği ve iş tatmininin bu ilişkide ayrıca aracıllı rolü üstlendiğ $i$ belirlenmiştir. Alt boyutlar açısından incelendiğinde, performans ve ücret uygulamaları ile iş tatmini ve alt boyutları olan içsel ve dışsal tatmin arasında pozitif bir ilişki olduğu ancak ücret uygulamalarının duygusal bağgllı̆̆ pozitif yönde etkilemediği, dolayısı ile içsel ve dışsal tatminin ücret ile duygusal bağglllk arasında aracılık rolü üstlenmediği görülmüştür.
\end{abstract}

Anahtar Kelimeler: Performans, Ücret, İş Tatmini, Örgütsel Bağlılık

JEL Sinıflandırması: D23, J24, J28, M12, M52

\section{The Impact of Perception of Performance Appraisal And Compensation Applications on Job Satisfaction And Commitment: An Application}

\begin{abstract}
The research was conducted on 5-star hotels operating in Istanbul. The relationship between job satisfaction and organizational commitment and subscales of performance and compensation practices in the research is examined. In this study, it was found that the perceptions about performance and compensation applications positively affect organizational commitment and job satisfaction, and that job satisfaction also has an intermediary role in this relation. When examined from the perspective of sub-dimensions, there is a positive relationship between performance and compensation practices with job satisfaction and sub-dimensions but found that compensation practices did not affect emotional commitment positively, so that internal and external satisfaction did not play a mediating role between compensation and emotional commitment.
\end{abstract}

Keywords: Performance, Compensation, Job Satisfaction, Commitment

JEL Classification: D23, J24, J28, M12, M52

\section{GíRIŞ}

Küreselleşme, endüstri toplumundan bilgi ve tüketim toplumuna geçiş, teknolojik ve sosyal gelişmelere bağlı müşteri ve çalışan beklentilerinin değişmesi, örgütleri birçok belirsizlik ile karşı karşıya bırakmıştır. Bu belirsizliklerle mücadele etmek için değer üretmek ve değişime ayak uydurmak gerekmektedir. Değişime

\footnotetext{
* Doktora Öğrencisi, İstanbul Aydın Üniversitesi, Sosyal Bilimler Enstitüsü, İşletme Yönetimi,selim.duzgun@gmail.com,

*** Prof. Dr., İstanbul Aydın Üniversitesi, İşletme Fakültesi, akinmarsap@aydin.edu.tr
} 
ayak uydurarak toplum için değer üretmek, örgütlerin kaynaklarını etkin ve verimli kullanmasına bağlıdır.

Günümüzde rekabet gücü elde etmek için birçok üretim faktörünün kolayca taklit edilebilmesi ya da elde edilebilmesi sebebi ile taklit edilmesi çok zor olan insan faktörünün önemini arttırmıştır. Bu açıdan insan kaynağının elde tutulması ve verimli kullanılması örgütler için kritik başarı faktörü haline gelmiştir. Dolayısıyla insan kaynakları bölümlerinin önemi artmıştır(Ekmekçi,2018:685)

Günümüz örgütlerinde insan kaynakları bölümü; seçme yerleştirme, işe alıştırma, performans değerlendirme, ücretleme-ödüllendirme ve isteklendirme gibi faaliyetleri üstlenmiştir(Tüzüner,2014:9). İnsan kaynakları bölümü genel olarak bu faaliyetlerle ilgili sistem ve yaklaşımların geliştirilmesi ve sürdürülmesi konusunda çalışmalar yürütmektedir.

Hizmet sektöründe yer alan Turizm sektörünün önemli bileşenlerinden olan otel işletmelerinde sunulan hizmetleri karşılayanı olarak çalışanlar hassas ve dinamik bir olgu olarak karşımıza çıkmaktadır. Fiziksel ve duygusal emeklerini ortaya koyan otel çalışanlarının memnuniyeti ve bağlılığı hizmet kalitesine etki edeceğinden bunu sağlamak için yapılacak çalışmalar stratejik açıdan değer ifade etmektedir(Akgöz ve Arac1,2018:179). Bu sebeple çalışmada insan kaynakları fonksiyonlarından performans ve ücret uygulamalarının örgütsel bağlllık ve iş tatminine olan etkisi araştırılmıştır.

\section{KAVRAMSAL ÇERÇEVE}

\section{A. Performans Yönetimi}

Performans, bir işin üstesinden gelerek belirlenmiş amaçlara ulaşma durumunu ifade eder. Performans; bir iş veya görev ile ilgili süreç ve kişilerin; kaynaklar, amaçlar ve sonuçlar doğrultusunda hazırlanan kriterlere göre nitel ve nicel olarak ölçülmesi ile elde edilen sonuçlar olarak tanımlanabilir (Şendoğdu, 2014:53).

Örgütler amaçlarına ulaşmak için öncelikle faaliyetlerini planlar, bu planlara göre işleri dizayn edip iş sistemleri kurarlar. İş sistemlerine ve süreçlerine uygun yetkinlikte işgörenleri istihdam ederler. İstihdam edilen kişileri işe adapte eder, eğitir, kendilerinden beklenen görevleri ve rolleri paylaşırlar. Belirtilen hedefler doğrultusunda motive eder ve ödüllendirir. Bu akış, örgütlerin amaçlarına ulaşmak için takip ettikleri temel yoldur. Bu açıdan performans değerlendirme bir kontrol mekanizması olmanın yanında örgütte işlerin nasıl sürdürüldüğünü görmek ve takip etmek açısından önemli bir insan kaynakları fonksiyonudur.

Performans yönetimi, çalışan hedefleri ile örgüt hedeflerinin uyumlaştırılması amacı ile performans değerlendirme sisteminin diğer insan kaynakları sistemleri ile entegre edildiği, performansın planlandığı, değerlendirildiği ve geliştirildiği bir süreçtir (Özer vd., 2017:280; Çetin vd. 2017:151; Sims, 2002:199). Dolayıs1 ile stratejilerin belirlenmesi, planların geliştirilmesi ve uygulanması, sonuçların analiz edilmesi ve buna göre kararların verilmesi için bütün süreçlerin, bilgilerin ve sistemlerin göz önüne alındığ genel bir süreç olarak ifade etmek mümkündür (Axson,2010:25). Performans yönetimi, çalışanın işe alımından kurumdan ayrılmasına kadar olan süre içinde, amaç ve 
davranış uyumunun maksimum düzeye çıkarılması için gerekli faaliyetlerin icra edilmesini gerektirir. Böylelikle hem çalışanın hem de örgütün beklentileri tam olarak karşılanmış olur.

İşletmenin genel performansı, bireylerin performanslarının toplamı olarak nitelendirildiğinden bireysel performansın doğru ve objektif ölçülmesi sistemden beklenen faydanın elde edilmesi açısından önemlidir. Çeşitli araştırmalarda adil bir performans sisteminin, örgütün başarısında etkili ve önemli bir faktör olduğu tespit edilmiştir (Singh ve Rana, 2014:128). Bu araştırmalarda; performans sistemine ilişkin adalet algısının, çalışanları performans sisteminden tatmin ve kabullenme düzeyini ve sistemin başarısını etkilediği bulunmuştur. Olumlu algılar, pozitif bir iş ortamı oluşmasına ve örgüt performansının artmasına katkı sağlamaktadır (Bekele vd., 2014:137). Bu sebeple performans sisteminin adil ve şeffaf bir şekilde, örgütün amaçları ve kültürü doğrultusunda tasarlanması önemlidir. Bir örgütte performans sisteminin varlığ 1 hem örgüte hem yöneticilere hem de çalışanlara önemli katkılar sağladığını ifade etmek mümkündür.

\section{B. Ücret Sistemi}

Ücret, bir örgütte belli bir zaman diliminde işgörenin bedensel ve zihinsel emeğinin karş1lığı olarak işgörene sağlanan para veya para ile ölçülebilen maddi menfaatler toplamıdır (Güney, 2015:252, Ergeneli vd., 2016:301).

Örgütler ücreti, amaçlarına ulaşmak için ihtiyaç duydukları iş gücünü örgüte çekmek, örgütte tutmak, tatmin etmek ve motive etmek için kullanırlar. Bu sebeple örgütlerin katlanmak zorunda oldukları önemli bir maliyet kalemidir. Örgüt stratejilerinin uygulanması ve sürekliliğinin sağlanması işgörenlerin bilgi, beceri ve yeteneklerine bağlıdır. Nitelikli işgörenlerin örgüte cezbedilmesi ve onları tatmin edecek ücretlerin verilmesi, örgüt stratejilerinin yerine getirilmesini etkin hâle getirmektedir. Bunun yanında işgörenlerin motivasyonları, iş tatminleri ve kuruma bağl11ıkları da örgütün başarısı için önemli bir faktördür. Bu açıdan bakıldığında işgörenlere verilen ücret önemli bir maliyet kalemi olmasına rağmen örgütlerin amaçlarına ulaşmasında da kilit bir rol üstlenmektedir.

Ücret bileşenleri; temel ücret, değişken ücret, ek yarar ve sosyal haklar olarak ifade etmek mümkündür. Maaş olarak da nitelendirilen temel ücret; bütçe doğrultusunda işgörene belirli bir zaman dilimi için garanti edilmiş ve yapılan işin örgüt için değerine göre belirlenmiş kök ücrettir. Teşvik edici veya özendirici olarak kişilerin performansı ve kuruma katkısı esas alınarak temel ücret haricinde verilen ek ödemeler, değişken ücret olarak nitelendirilir (Torrington vd.,2008:634636). Ek yarar ve sosyal menfaatler(Yan Haklar), temel ücret ve değişken ücret haricindeki bütün menfaatleri kapsamaktadır. Bu ödemeler, işgörenin kuruma bağl1lığına ve verimli çalışmasına pozitif katkılar sağlar. Örgütler ek menfaat ve yararlar sağlayarak yetkin adayları cezbedip örgütte kalmalarını temin eder (Shields, 2007:320). Ek yarar ve sosyal menfaatler; kâr pay1, ikramiye, yemek, servis, sağlık ve hayat sigortası, konut, yakacak yardımı, izinli ve raporlu günlerde ücretlerin ödenmesi ile yöneticilere lojman, araba, yakıt yardımı gibi ödemeler olarak suralanabilir (Sabuncuoğlu, 2012:246). 
Mehmet Seliim Düzgüm \& Akın Maşrap/Performans Değerlendirme Ve Ücret Uygulamalarına İlişkin Algının İş Tatmini Ve Örgütsel Bă̆lılığa Etkisi: Bir Uygulama

Ücret sisteminin, uygulayıcılar ve çalışanların rahatça anlayıp uygulayabileceği bir yapıda olması, adil, özendirici ve iş odaklı bir kurguya dayandırılması gerekmektedir. Ücret sistemleri kurgulanırken, örgüt içinde bir denge kurulmasını sağlarken dış çevre ile rekabet etmeye ve yetenekleri kuruma çekmeye katkı sağlaması gerekmektedir (Çetin vd., 2017:187). Bunun yanında örgütün amaçlarına ulaşmasına da katkı sağlamalıdır. Ayrıca ücret sistemi kurulum çalışmalarında; ücretlerin piyasaya göre konumlandırılması, çalışanların yaptıkları işin niteliğine ve çalışma şekillerine göre ödeme türlerini belirlemesi, ücret artış ve düzeltme stratejisi de belirlenmelidir(Ergeneli vd., 2016:303).

Örgütlerdeki ücret sistemlerinin en önemli amaçlarından bir tanesi işgörenlerin kurumda verimli bir şekilde çalışmasını sağlamak olduğunu söylemek mümkündür. Performansa dayalı ücretleme sistemi de rekabetçi temellere dayandırıldığından bireyin, dolayısı ile kurumun performansını artıracağı varsayılmaktadır.

Bireysel performansa dayalı ücret sistemleri, çalışanların performansı ve elde ettikleri başarı oranında ücretlemeyi esas alan sistemlerdir. Performans ile ücret arasında ilişki kurması dolayısı ile çalışanı daha gayretli ve rekabetçi davranmaya teşvik eder (Erel ve Yalçın, 2014:319). Örgütler, bireysel performansı esas alan ücret sistemlerini, stratejik hedeflerine çalışanları vasıtası ile daha etkin bir şekilde ulaşmak, çalışanlarının gelirlerini artırmak ve ödüllendirmek, verimlilik ve kalite hedeflerine ulaşmak ve potansiyeli olan çalışanı kuruma çekmek için kullanırlar (Dolgun, 2012:211).

\section{C. İş Tatmini ve Örgütler İçin Önemi}

İş tatmini, iş ve iş çevresine yönelik tutumların toplamı olarak ifade edilebilir (Mcshane ve Glinow, 2016:74). Başka bir tanıma göre; iş tatmini, kişinin beklentileri doğrultusunda elde ettiklerine karşı gösterdiği duygusal bir tepkidir. Dolayısı ile iş tatmini, çalışanın iş yeri ve görevi ile ilgili genel duygularının seviyesi olarak tanımlanabilir (Javed vd., 2014:123). Aslında iş tatmini, kişinin iş yerinde önem verdiği hususların sağlanması neticesinde oluşan bir durumdur (Özkalp vd., 2013:50). Önem verilen konular herkese göre değiştiği için iş tatmini birçok farklı parametreye bağlı olmaktadır. Aslında iş tatmini farklı kişiler için farklı anlamlara sahip karmaşık ve çok boyutlu bir kavramdır. Motivasyon kavramı ile kullanılmasına rağmen bu kelime ile aynı anlamı taşımaz. İş tatmini bir hâl veya iç durumu ifade eden bir kavramdır. İş tatmini, motivasyonu artıran ve yüksek performansa zemin hazırlayan bir durumdur. Kişinin işinden tatmin olma düzeyi bireysel, sosyal, kültürel, örgütsel ve çevresel faktörlere bağlıdır (Mullins, 2010:282). Bu çerçevede farklı kültürlerde yetişmiş çalışanların iş tatmin kriterleri ve düzeyleri farklı olabilmektedir.

Yüksek rekabet ortamında örgütlerin müşteri ihtiyaçlarını karşılamaları, rekabet avantajı elde etmeleri için farklı yetenekleri olan, entelektüel kapasitesi yüksek, insan ilişkiler konusunda hünerli çalışanlara ve bu çalışanları etkin bir şekilde örgütte tutmaya ihtiyaçları vardır (Vasudevan, 2014:14). İş tatmini çalışanın göstereceği çabanın niteliğini ve düzeyini etkilediğinden yüksek iş tatmini, örgütte verimliliği ve örgütün bütünsel performansını arttırmaktadır 
(Muguongo vd., 2015:47).

Yapılan araştırmalarda iş tatmininin sadece örgütlerin operasyonel başarısını arttırmadığı, stratejik başarısına da olumlu katkılar yaptığı tespit edilmiştir (Özkalp vd., 2013:49). Javed ve arkadaşlarının 2014'te yaptığı çalışmada iş tatmininin, sadakat ve iş performansını olumlu etkilediği, işten ayrılma niyetini negatif etkilediği bulunmuştur (Javed vd., 2014:120-121). Sacchetti ve arkadaşları 4134 çalışan ile yaptıkları çalışmada insan kaynakları uygulamalarının tatmini arttırdığını, bunun da örgütsel performans üzerinde olumlu bir etkisi olduğunu bulmuştur (Sacchetti vd., 2016:4). Awan ve Safraz (2013) yaptıkları çalışmada insan kaynakları uygulamalarının iş tatmini aracı rolü ile örgütsel performansla güçlü pozitif bir ilişki içinde olduğunu bulmuşlardır (Munjuri ve K'obonyo, 2015:164). Özetle iş tatmininin yüksek performans için gerekli olduğunu, insan kaynakları uygulamalarının ise iş tatminini artırdığını söylemek mümkündür.

İş tatmini kavramının temelini güdüleme ile ilgili araştırmalar oluşturmaktadır. Örgütsel davranışın önemli konularından birisi olan iş tatmini, motivasyon kuramları ile literatüre girmiştir. İhtiyaçlara bağlı iş tatminini ele alan teoriler kapsam teorileri olarak sınıflandırılırken performansa bağlı iş tatminini ele alan teoriler, beklenti teorileri olarak sınıflandırılmıştır. Kapsam teorileri, ihtiyaçların tatmin edilmesine odaklanırken beklenti teorileri; ihtiyaçlar, değerler ve beklentilerin etkileşimi çerçevesinde iş tatminini ele almıştır (Köroğlu, 2012,277).

İş tatmini ile ilgili teorileri; Maslow'un İhtiyaçlar Hiyerarşisi, Alderfer' in ERG, Locke'un Amaçlama, McClelland'ın Başarı Güdüsü, Herzberg'in Çift Etmen, Beklenti ve Eşitlik Teorileri olarak sıralayabiliriz. Bu çalışmada iş tatmini, Herzberg tarafından öne sürülen teori çerçevesinde ele alındığından Herzberg'in çift etmen teorisinden kısa bahsetmek faydalı olacaktır.

Frederick Herzberg'in çift faktör teorisinde, çalışanların işlerinden ne beklediklerini tespit etmek için iş yerinde kendilerini ne zaman iyi ve ne zaman kötü hissettikleri durumları belirtmeleri, özellikle iyi ve kötü hissetmelerinin sebeplerini belirtmeleri istenmiştir (Mullins, 2010:265). Bu durumların incelenmesi neticesinde bazı faktörlerin motive edici(İçsel) nitelikte olduğu, bazı faktörlerin ise hijyen faktörler(D1şsal) olduğu tespit edilmiştir (Tuna, 2016:286).

Hijyen faktörler insanlarda belli bir doyum düzeyini korumak için gerekli olan, iş güvenliği, fiziksel şartlar, ücret, ilişkiler ve iletişim gibi faktörleri barındıran dışsal faktörlerdir. Durum koruyucu faktörler olarak da nitelendirilen bu faktörler, bir görevin sürdürülmesini ve motive olmak için gerekli asgari koşulların sağlanmasına katkı sağlamaktadır. Hijyen faktörler karşılandığında insanlar tatminsizlik hissetmemekte ancak tatmin de olamamaktadırlar (Kitchin, 2010;6970). Yani hijyen faktörler, tatmin ve motivasyon için gerekli ancak yeterli nitelikte değildir.

Herzberg'e göre insanların motive olmaları için kendilerini iyi hissettikleri konular olan gelişme, başarı, takdir, sorumluluk alma, ilerleme imkânları gibi içsel faktörlerin var olması gerekir. Tatmini sağlayan faktörler ile tatminsizliğe neden olan faktörler ayrıdır. Tatminsizliğe neden olan faktörler ortadan kaldırılsa dahi 
tatmin sağlanamayabilir (Robbins \& Judge , 2015:208). Bu faktörlerin ortadan kalkması sadece motivasyon için uygun bir ortamın oluşmasını sağlar. Motivasyon için mutlaka motive edici faktörlerin olması gerekir. Böylece motivasyon için ihtiyaç duyulan bütün şartlar sağlanmış olur.

\section{D. Örgütsel Bağlılık ve Örgütlerde Artan Önemi}

Kişinin işine ve çalışma şartlarına, çalışma arkadaşlarına, yönetime ve örgütün geneline karşı takındığı tavır ve tutum olarak ifade edilen (Küçüközkan, 2015:14-15) örgütsel bağlılık, çalışanın örgüte karşı hissettiği olumlu duyguların toplamıdır (Eren ve Bal, 2015:44). Bu anlamda örgütsel bağl1lık, birey ve örgüt arasındaki ilişkilerin güçlendirilmesi temeline dayanan ve örgüt ile birey arasındaki psikolojik bağı ifade eden bir kavramdır (Demirel ve Akça, 2008:45). Örgütsel bağl1l1k, rekabet üstünlüğü elde etmek ve muhafaza etmek için ihtiyaç duyulan bilgi, beceri ve yetkinliklere sahip kişilerin elde tutulması ve potansiyellerinin ortaya çıkarılması için gerekli çalışmaları yapmak anlamına gelen günümüz güncel kavramlarından yetenek yönetiminin de kritik konularındandır (Kaliannan ve Adjovu, 2015:162-163).

Örgütsel bağlılık, insan kaynakları yönetiminin kalbinde yer alan bir kavramdır. Çünkü bütün insan kaynakları süreçlerinin etkinliğinin göstergesi, örgütsel bağlılığ yüksek olan verimli çalışandır. Örgütsel bağlılık, çalışanın potansiyelini ortaya koymasını ve potansiyelini arttırmasına katkı sağlar (Hassan and Mahmood, 2016:25) .

Yapılan birçok çalışmada örgütsel bağlılı̆̆ın; iş tatmini, motivasyon, işe devam ve performans gibi hususları pozitif etkilediği, devamsızlık ve devir hızı gibi hususları negatif etkilediği (Tekingündüz ve Tengilimoğlu, 2013:80), finansal performansı, bireysel ve örgütsel başarıyı arttırdığını belirlenmiştir (Selvarasu ve Sastry, 2014:11).

Literatür incelendiğinde ise bağl1lı çeşitli araştırmacılar tarafından farklı biçimlerde sınıflandırılmıştır. Literatürde yapılan araştırmaların çokluğu ve çalışmaların yoğunluğu sebebi ile bu çalışmada Allen ve Meyer'in sınıflandırması çerçevesinde araştırma yapılmıştır. Allen ve Meyer örgütsel bağl1lığ "duygusal bağlılık", "devam bağlılı̆̆ı" ve "normatif bağlilık" olarak sinıflandırarak ele almıştır. Bu açıdan Allen-Meyer sınıflandırmasındaki örgütsel bağlılık boyutlarının kısaca açıklanması faydalı olacaktır.

Duygusal bağ l1lık, çalışanın kurumuna karşı hissettiği sadakat ve duygusal yakınlıktır (Mcshane and Glinow, 2016:77). Devam bağl1lı̆̆1, rasyonel bağl1lık olarak da ifade edilir. Çünkü devam bağlılığında, harcanan zaman ve emek, gösterilen çaba gibi iş ile ilişkili hususlar ile yeni iş arama, taşınma gibi iş dışındaki maliyetlerin hesaba katılması sonucunda örgütte çalışmaya devam etme kararı alınır (Karcıoğlu ve Çelik, 2012:63). Normatif bağl1lık, en azından bir süreliğine örgütte kalmanın, alınan bir eğitim veya işgörene sağlanan başka bir katkı dolayısı ile örgütte kalmanın ahlaki olarak değerlendirildiği bir durumdur (Shields, 2007:44).

\section{ARAŞTIRMA}

\section{A.Araştırmanın Konusu, Amacı ve Önemi}


$\mathrm{Bu}$ çalışmada performans değerlendirme ve ücret uygulamalarına ilişkin algının çalışanların örgütsel bağlılıkları ve iş tatminlerine etkisi ve iş tatmininin aracılık rolü araştırılmıştır. Çalışmanın, birkaç kavram arasındaki ilişkileri incelemesi, insan gücüne dayalı hizmet sektöründen biri olan otel ve konaklama işletmelerinde yapılması ve bu konuda beş yıldızlı otellerde yapılan çalışmaların çok sınırlı olması sebebi ile literatüre önemli bir katkı yapmak amaçlanmıştır.

\section{B. Araştırmanın Varsayımı, Sınırlılıkları ve Kapsamı}

Araştırmada örneklem, küme örneklemesi metodu ile belirlenmiştir. Araştırma, Türkiye'deki bütün beş yıldızlı otellere ulaşmanın zorluğu, zaman ve imkân kısıtları dolayısıyla İstanbul' da faaliyet gösterip çalışanlarını bir performans sistemi dâhilinde değerlendiren beş yıldızlı konaklama işletmeleri ile sınırlandırılmıştır. Kültür ve Turizm Bakanlığı veri tabanındaki Mayıs 2016 verilerine göre İstanbul'da bulunan 5 yıldızlı otel sayısı 86'dır. Araştırma konusu itibari ile doğru ölçümlemenin yapılması için özellikle performans uygulamalarının var olup olmadığını tespit etmek için bu oteller ile telefon görüşmeleri ve mülakatlar yapılmıştır. Görüşme ve mülakatlar neticesinde 33 otelde performans sisteminin var olduğu tespit edilmiştir.

Araştırma için uygun olan 33 otelden 15 'i teadüfi olarak seçilmiş ve 750 anket yollanmıştır. 440 anket geri toplanmış ve istatistik analiz için 391 anket anlamlı bulunmuştur.

Araştırma İstanbul'daki 5 yıldızlı otelleri kapsadı̆̆ından elde edilen sonuçlar örneklem ile kısıtlıdır. Bu sebepten elde edilen sonuçların diğer sektörler ve diğer turizm işletmeleri için genelleştirilmesi mümkün değildir.

\section{Araştırmanın Modeli}

Araştırmanın bağımsız değişkenleri, performans değerlendirme uygulamalarına ilişkin alg1 ve ücret uygulamalarına ilişkin algıdır. Bağımlı değişkenler ise örgütsel bağl1lı ve iş tatminidir. Örgütsel bağl11ı̆̆ın alt boyutlarından olan zorunlu (normatif) bağlılığ olumsuz etkilediğinden modelden çıkartılmıştır. Bu sebeple örgütsel bağlılık, duygusal ve devam bağlılığı olmak üzere iki alt boyuta ayrılmaktadır. İş tatmini ise içsel ve dişsal tatmin olmak üzere iki ana alt boyuta ayrılmaktadır. Alt boyutlarla araştırmanın kavramsal modeli aşağıdadır:

Şekil 1: Araştırma modeli

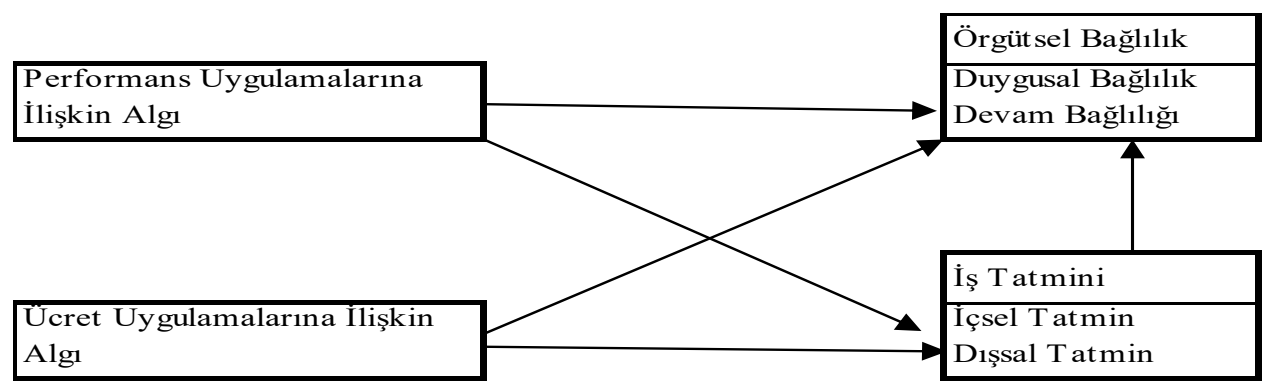

\section{Araştırmanın Hipotezleri}

Araştırmanın hipotezleri, çalışmanın literatür kısmında incelendiği üzere 
performans ve ücret uygulamalarına ilişkin algının iş tatmini ve örgütsel bağl1lı̆̆ etkilediği ve iş tatmininin, performans ve ücret uygulamalarına ilişkin algı ile örgütsel bağlılık arasında aracılık rolü üstlendiği varsayımı ile hazırlanmıştır. Buna göre araştırma için 22 hipotez hazırlanmış ancak sadelik açısından 14 hipotez ele alınmıştır.

H1: PDUİA, İT'ni olumlu yönde etkiler

H2: ÜUİA, İT'ni olumlu yönde etkiler

H3: ÜUİA, DT'ni olumlu yönde etkiler

H4: PDUİA, DT'ni olumlu yönde etkiler

H5: PDUİA, DB'ı olumlu yönde etkiler

H6: ÜUİA, DB'1 olumlu yönde etkiler

H7: PDUİA, DEB'nı olumlu yönde etkiler

H8: ÜUİA, DEB'nı olumlu yönde etkiler

H9: İT, PDUİA ile DB arasında aracılık rolü üstlenir

H10: ITT, PDUIA ile DEB arasında aracilık rolü üstlenir

H11: İT, ÜUİA ile DEB arasında aracılık rolü üstlenir

H12: DT, PDUIA ile DB arasında aracılık rolü üstlenir

H13: DT, PDUİA ile DEB arasında aracılık rolü üstlenir

H14: DT, ÜUİA ile DEB arasında aracılık rolü üstlenir

\section{E. Araştırmanın Veri Toplama Yöntem ve Araçları}

Araştırmada veri toplama aracı olarak anket yöntemi kullanılmıştır. Örgütsel bağl1lık için Allen-Meyer tarafından 1991 yılında geliştirilen bağlılık ölçeği kullanılmıştır. Ölçek üç alt faktörü(duygusal, normatif ve devam bağlılığı) ölçen toplam 18 sorudan oluşmaktadır. İş tatmini için Minnesota üniversitesi araştırmacıları tarafından 1967 yılında geliştirilen Minnesota İş tatmini ölçeği kullanılmıştır. Ölçekte temel olarak iş koşulları ile iş tatmini ilişkilendirilmektedir. Minnesota İş Tatmin Ölçeği(MSQ); içsel tatmin, dışsal tatmin ve genel tatmin düzeyini belirleyici özelliklere sahip 20 maddeden oluşmaktadır.

Performans ve ücret uygulamalarına ilişkin algı ölçeği için 54 adet makale ve tez incelenmiştir. Bu çerçevede Singh ve Wahla'nın (2015) konu ile ilgili makalesi, Bekele ve arkadaşlarının 2014'teki makalesi ile Felicia Tucker (2014), Akbıyık'ın (2012) hazırladıkları doktora tezlerinde kullanılan anketler detaylı incelenmiştir. Çalışmanın aynı sektörde yapılması ve benzer çalışan kitlesi üzerinde daha önce yapılması dolayısı ile Akbıyık'ın 2012 yılında bu konuda kullandığı anket soruları kullanılmıştır. Bu ankette 6's1 performansa, 6's1 da ücrete ilişkin algıyı ölçen soru olmak üzere toplam 12 madde bulunmaktadır.

Demografik kısım ise cinsiyet, yaş, eğitim durumu, sektör tecrübesi, görev süresi, otelde çalışma süresi, otelde çalış1lan görev süresi, çalışılan bölüm, icra edilen görev, çalışma şekli (tam zamanl1-yarı zamanlı) ve çalışma biçimini (tüm yıl çalışma-mevsimsel çalışma) ihtiva eden sorulardan oluşmaktadır.

\section{F. Araştırmada Kullanılan İstatistiki Teknikler Ve Ölçekler}

Araştırmada elde edilen veriler SPSS programı kullanılarak analiz edilmiştir. İki bağımsız grup arasında verilerin karşılaştııılmasında t-testi, ikiden fazla bağımsız grup arasında verilerin karşılaştırılmasında tek yönlü (One way) 
ANOVA testi kullanılmıştır. ANOVA testi sonrasında farklılıkları belirlemek üzere tamamlayıcı post-hoc analizi olarak Scheffe testi uygulanmıştır. Araştırmanın sürekli değişkenleri arasında Pearson korelasyon analizi uygulanmıştır.

Araştırmanın modeli Baron ve Kenny (1986) tarafından ifade edilen ara değişken kriterlerine göre analiz edilmiştir. Baron ve Kenny'e göre bir değişkenin ara değişken olabilmesi için(Baron ve Kenny,1986:1176):

- $\quad$ Bağımsız değişkenin ara değişken üzerinde bir etkisinin olması

- Bağımsız değişkenin bağımlı değişkende bir etkisinin olması

- $\quad$ Ara değişkenin bağımlı değişken üzerinde bir etkisinin olması ve ara değişkenin modele eklenmesi ile bağımsız değişkenlerin bağımlı değişken üzerindeki etkisini kaybetmesi (tam ara değişken) veya etkisinde azalma olması (kısmi ara değişken) şartları aranır.

Hiyerarşik regresyon modelleri uygulandıktan sonra aracılık etkisini ölçmek için Sobel tarafından geliştirilen test uygulanmıştır. Elde edilen bulgular $\% 95$ güven aralığında, \%5 anlamlılık düzeyinde değerlendirilmiştir.

\section{Örgütsel bağlılık ölçeği faktör analizi}

Örgütsel bağlllık ölçeğinin güvenirlilik ve geçerliliğini ortaya koymak için açıklayıcı (açımlayıcı) faktör analizi yöntemi uygulanmıştır. Örgütsel bağlılı̆̆ın alt boyutlarından olan zorunlu (normatif) bağlılı̆̆ olumsuz etkilediğinden modelden çıkartılmıştır. Ölçekten 11 numaralı ifade eş yükleme olduğundan çıkartılmıştır. Yapılan Barlett testi sonucunda $(p=0.000<0.05)$ faktör analizinde ele alınan değişkenler arasında ilişkinin olduğu tespit edilmiştir. Yapılan test sonucunda $(\mathrm{KMO}=0.804>0,60)$ örnek büyüklüğünün faktör analizi uygulanması için yeterli olduğu tespit edilmiştir. Faktör analizi uygulamasında varimax yöntemi seçilerek faktörler arasındaki ilişkinin yapısının aynı kalması sağlanmıştır. Faktör analizi sonucunda değişkenler, toplam açıklanan varyans1 \%64.037 olan 2 faktör altında toplanmıştır (Çizelge 1). Ölçeğin genel güvenirliliği alpha $=0.817$ olarak yüksek bulunmuştur. Güvenirliliğine ilişkin bulunan alpha ve açıklanan varyans değerine göre örgütsel bağlılık ölçeğinin geçerli ve güvenilir bir araç olduğu anlaşılmıştır. Ölçeğe ait oluşan faktör yapısı aşağıdaki çizelgede görülmektedir:

Çizelge 1: Örgütsel Bağlılık Ölçeği Faktör Yapısı

\begin{tabular}{|c|c|c|c|c|}
\hline Boyut & Madde & Faktör Yükü & Açıklanan Varyans & Cronbach's Alpha \\
\hline Duygusal Bağlılık(Özdeğer=3.421) & Bağlılık5 & 0,892 & \multirow{6}{*}{42,354} & \multirow{6}{*}{0,863} \\
\hline & Bağlılık4 & 0,880 & & \\
\hline & Bağlılık3 & 0,860 & & \\
\hline & Bağlılık2 & 0,800 & & \\
\hline & Bağl1lık1 & 0,776 & & \\
\hline & Bağl11ık6 & 0,721 & & \\
\hline \multirow[t]{5}{*}{ Devam Bağlılı̆̆ı(Özdeğer=2.583) } & Bağl1lık12 & 0,725 & \multirow{5}{*}{21,683} & \multirow{5}{*}{0,754} \\
\hline & Bağlılık10 & 0,710 & & \\
\hline & Bağlılık9 & 0,696 & & \\
\hline & Bağl1lık8 & 0,649 & & \\
\hline & Bağl1lık7 & 0,556 & & \\
\hline
\end{tabular}




\section{Performans değerlendirme ve ücret uygulamalarına ilişkin algı ölçeği faktör analizi}

İç tutarlılık güvenilirliğini belirlemek için en çok Cronbach alfa değerinden yararlanılır. Alfa değerinin en az 0,70 olması gerekir. KMO yeterlilik testi ise örneklemden toplanan verilerin faktör analizi için yeterli sayıda olup olmadığını test eder. KMO değerinin 0,50'nin üzerinde olması, örneklem hacminin faktör analizi için yeterli olduğunu gösterir(Köse,2017:130,173).

Performans değerlendirme ve ücret uygulamalarına ilişkin algı ölçeğindeki 12 maddenin güvenirliliği alpha $=0.914$ olarak çok yüksek bulunmuştur. Ölçeğin yapı geçerliliğini ortaya koymak için açılayıcı (açımlayıcı) faktör analizi yöntemi uygulanmıştır. Yapılan Barlett testi sonucunda $(\mathrm{p}=0.000<0.05)$ faktör analizine alınan değişkenler arasında ilişkinin olduğu tespit edilmiştir. Yapılan test sonucunda $(\mathrm{KMO}=0.928>0,60)$ örnek büyüklüğünün faktör analizi uygulanması için yeterli olduğu tespit edilmiştir. Faktör analizi uygulamasında varimax yöntemi seçilerek faktörler arasındaki ilişkinin yapısının aynı kalması sağlanmıştır. Faktör analizi sonucunda değişkenler, toplam açılanan varyansı \%67.869 olan 2 faktör altında toplanmıştır (Çizelge 2). Güvenirliliğine ilişkin bulunan alpha ve açıklanan varyans değerine göre performans değerlendirme ve ücret uygulamalarına ilişkin algı ölçeğinin geçerli ve güvenilir bir araç olduğu anlaşılmıştır. Ölçeğe ait oluşan faktör yapısı aşağıda görülmektedir:

Çizelge 2: Performans Değerlendirme Ve Ücret Uygulamalarına İlişkin Algı Ölçeği Faktör Yapısı

\begin{tabular}{|c|c|c|c|c|}
\hline Boyut & Madde & Faktör Yükü & $\begin{array}{c}\text { Açıklanan } \\
\text { Varyans }\end{array}$ & $\begin{array}{c}\text { Cronbach's } \\
\text { Alpha }\end{array}$ \\
\hline $\begin{array}{l}\text { Ücret Uygulamalarına İlişkin } \\
\text { Algl(Özdeğer }=6.534)\end{array}$ & Performans Alg 7 & 0,832 & \multirow{6}{*}{38,467} & \multirow{6}{*}{0,902} \\
\hline & Performans Alg1 9 & 0,826 & & \\
\hline & Performans Alg 18 & 0,817 & & \\
\hline & Performans Alg 11 & 0,805 & & \\
\hline & Performans Alg 10 & 0,752 & & \\
\hline & Performans Alg1 12 & 0,666 & & \\
\hline \multirow[t]{6}{*}{$\begin{array}{l}\text { Performans Değerlendirme } \\
\text { Uygulamalarına İliş̧in } \\
\text { Algı(Özdeğer=1.611) }\end{array}$} & Performans Alg 2 & 0,798 & \multirow{6}{*}{29,402} & \multirow{6}{*}{0,873} \\
\hline & Performans Algı 1 & 0,796 & & \\
\hline & Performans Alg1 4 & 0,787 & & \\
\hline & Performans Alg 13 & 0,766 & & \\
\hline & Performans Alg 6 & 0,638 & & \\
\hline & Performans Alg1 5 & 0,570 & & \\
\hline
\end{tabular}

\section{İş tatmini ölçeği faktör analizi}

İş tatmini ölçeğinin güvenirlilik ve geçerliliğini ortaya koymak için açıklayıcı (açımlayıcı) faktör analizi yöntemi uygulanmıştır. Ölçekte 11,15 ve 20 numaralı maddeler eş yükleme olduğundan ölçekten çıkartılmıştır. Yapılan Barlett 
testi sonucunda $(\mathrm{p}=0.000<0.05)$ faktör analizine alınan değişkenler arasında ilişkinin olduğu tespit edilmiştir. Yapılan test sonucunda $(\mathrm{KMO}=0.948>0,60)$ örnek büyüklüğünün faktör analizi için yeterli olduğu tespit edilmiştir. Faktör analizi uygulamasında varimax yöntemi seçilerek faktörler arasındaki ilişkinin yapısının aynı kalması sağlanmıştır. Faktör analizi sonucunda değişkenlerin toplam açıklanan varyansı \%56.889 olan 2 faktör altında toplanmıştır (Çizelge 3). Ölçeğin genel güvenirliliği alpha $=0.939$ olarak çok yüksek bulunmuştur. Bulunan alpha ve açıklanan varyans değerine göre iş tatmini ölçeğinin geçerli ve güvenilir bir araç olduğu anlaşılmıştır. Ölçeğe ait oluşan faktör yapısı aşağıda görülmektedir:

Çizelge 3: İș Tatmini Ölçeği Faktör Yapısı

\begin{tabular}{|c|c|c|c|c|}
\hline Boyut & Madde & Faktör Yükü & $\begin{array}{c}\text { Açıklanan } \\
\text { Varyans } \\
\end{array}$ & Cronbach's Alpha \\
\hline İçsel Tatmin(Özdeğer=8.639) & İt9 & 0,720 & \multirow{9}{*}{29,381} & \multirow{9}{*}{0,895} \\
\hline & İt2 & 0,709 & & \\
\hline & İt3 & 0,702 & & \\
\hline & İt10 & 0,694 & & \\
\hline & İt1 & 0,619 & & \\
\hline & İt16 & 0,613 & & \\
\hline & İt7 & 0,603 & & \\
\hline & İt4 & 0,600 & & \\
\hline & İt8 & 0,598 & & \\
\hline \multirow[t]{8}{*}{ Dışsal Tatmin(Özdeğer=1.032) } & Dt14 & 0,800 & \multirow{8}{*}{27,508} & \multirow{8}{*}{0,896} \\
\hline & Dt19 & 0,791 & & \\
\hline & Dt13 & 0,753 & & \\
\hline & Dt17 & 0,664 & & \\
\hline & Dt12 & 0,607 & & \\
\hline & Dt6 & 0,595 & & \\
\hline & Dt5 & 0,591 & & \\
\hline & Dt18 & 0,580 & & \\
\hline
\end{tabular}

\section{BULGULAR VE YORUMLAR}

$\mathrm{Bu}$ bölümde, araştırmaya katılan çalışanların ölçekler yoluyla toplanan verilerinin analizi sonucunda elde edilen bulgular ve bu bulgulara dayalı olarak açıklama ve yorumlar yapılmıştır.

\begin{tabular}{|c|c|c|c|c|c|c|c|}
\hline \multicolumn{8}{|c|}{$\begin{array}{l}\text { A.Araştırmaya Katılanların Performans Değerlendirme ve Ücret } \\
\text { Uygulamalarına İlişkin Algıları ile Örgütsel Bağlılık ve İs Tatmin Düzeyleri } \\
\text { Arasındaki İlişkiler(*) } \\
\text { Çizelge 4'te görüldüğ̈̈ü üzere bütün değişkenler arasındaki korelasyon } \\
\text { ilişkisi anlamlı ve pozitif olarak bulunmuştur }(\mathrm{r}>0 ; p=0,000<0.05) \\
\text { Çizelge 4: Çalışanların Bağllık, İş Tatmini, Performans Değerlendirme Ve Ücret Uygulamalarına } \\
\text { İlişkin Algıları Arasında Korelasyon İlişkisi }\end{array}$} \\
\hline & & 1 & 2 & 3 & 4 & 5 & 6 \\
\hline \multirow{2}{*}{$\begin{array}{l}\text { 1.Ücret uygulamalarına ilişkin } \\
\text { algı }\end{array}$} & & 1,000 & & & & & \\
\hline & & 0,000 & & & & & \\
\hline
\end{tabular}


Mehmet Seliim Düzgüm \& Akın Maşrap/Performans Değerlendirme Ve Ücret Uygulamalarına İlişkin Algının İş Tatmini Ve Örgütsel Bă̆lılı̆̆a Etkisi: Bir Uygulama

\begin{tabular}{|c|c|c|c|c|c|c|c|}
\hline \multirow{2}{*}{$\begin{array}{l}\text { 2.Performans değerlendirme } \\
\text { uygulamalarına ilişkin algı }\end{array}$} & $\mathrm{r}$ & $0,605^{* *}$ & 1,000 & & & & \\
\hline & $p$ & 0,000 & 0,000 & & & & \\
\hline \multirow[t]{2}{*}{ 3.İçsel tatmin } & $\mathrm{r}$ & $0,588^{* * *}$ & $0,608^{* *}$ & 1,000 & & & \\
\hline & $p$ & 0,000 & 0,000 & 0,000 & & & \\
\hline \multirow[t]{2}{*}{ 4.Dışsal tatmin } & $\mathrm{r}$ & $0,702 * *$ & $0,768 * *$ & $0,804 * *$ & 1,000 & & \\
\hline & $p$ & 0,000 & 0,000 & 0,000 & 0,000 & & \\
\hline \multirow[t]{2}{*}{ 5.Duygusal bağlılık } & $\mathrm{r}$ & $0,271^{* *}$ & $0,477 * *$ & $0,442 * *$ & $0,433 * *$ & 1,000 & \\
\hline & $p$ & 0,000 & 0,000 & 0,000 & 0,000 & 0,000 & \\
\hline \multirow[t]{2}{*}{ 6.Devam bağlılığı } & $\mathrm{r}$ & $0,474 * *$ & $0,363 * *$ & $0,559 * *$ & $0,497 * *$ & $0,161 * *$ & 1,000 \\
\hline & $p$ & 0,000 & 0,000 & 0,000 & 0,000 & 0,001 & 0,000 \\
\hline
\end{tabular}

(*): Performans değerlendirme Uygulamalarına İlişkin Algı: PDUİA, Ücret uygulamalarına İlişkin Algı: ÜUİA, Duygusal bağlılık: DB, Devam bağlılığı: DEB, İçsel İş Tatmini: İT, Dışsal İş Tatmini: DT

\section{B. Performans Değerlendirme Ve Ücret Uygulamalarına İlişsin Algı İle Duygusal Bağlılık Arasındaki İlişki Ve İçsel İş Tatminin Aracılık Rolüyle İlgili Testler Ve Bulgular}

Çizelge 5: Performans Değerlendirme Ve Ücret Uygulamalarına İlişkin Alg1 İle Duygusal Bağlılık Arasındaki İlişki Ve İçsel İş Tatmininin Aracılık Rolüyle İlgili Hiyerarşik Regresyon Modelleri

\begin{tabular}{|c|c|c|c|c|c|c|c|}
\hline Bağımlı Değişken & Bağımsız Değişken & B & $\mathbf{t}$ & $p$ & $\mathbf{F}$ & $\begin{array}{c}\text { Model } \\
(p)\end{array}$ & $\mathbf{R}^{2}$ \\
\hline İçsel Tatmin(Model1) & Sabit & 1,688 & 14,674 & 0,000 & \multirow{3}{*}{156,432} & \multirow{3}{*}{0,000} & \multirow{3}{*}{0,444} \\
\hline & $\begin{array}{l}\text { Ücret Uygulamalarına İlişkin } \\
\text { Algı }\end{array}$ & 0,272 & 7,336 & 0,000 & & & \\
\hline & $\begin{array}{l}\text { Performans Değerlendirme } \\
\text { Uygulamalarına İlişkin Alg1 }\end{array}$ & 0,330 & 8,381 & 0,000 & & & \\
\hline Bağımlı Değişken & Bağımsız Değişken & B & $\mathbf{t}$ & $p$ & $\mathbf{F}$ & $\begin{array}{c}\text { Model } \\
(p)\end{array}$ & $\mathbf{R}^{2}$ \\
\hline \multirow[t]{2}{*}{$\begin{array}{l}\text { Duygusal } \\
\text { Bağlilik(Model 2) }\end{array}$} & Sabit & 1,921 & 11,474 & 0,000 & \multirow[t]{2}{*}{94,421} & \multirow[t]{2}{*}{0,000} & \multirow[t]{2}{*}{0,193} \\
\hline & İçsel Tatmin & 0,436 & 9,717 & 0,000 & & & \\
\hline Bağımlı Değişken & Bağımsız Değişken & 及 & $\mathbf{t}$ & $p$ & $\mathbf{F}$ & $\begin{array}{c}\text { Model } \\
(p)\end{array}$ & $\mathbf{R}^{2}$ \\
\hline \multirow[t]{3}{*}{$\begin{array}{l}\text { Duygusal } \\
\text { Bağlılık(Model 3) }\end{array}$} & Sabit & 2,224 & 16,581 & 0,000 & \multirow{3}{*}{57,211} & \multirow{3}{*}{0,000} & \multirow{3}{*}{0,224} \\
\hline & $\begin{array}{l}\text { Ücret Uygulamalarına İlişkin } \\
\text { Alg1 }\end{array}$ & $\begin{array}{c}- \\
0,021 \\
\end{array}$ & $-0,482$ & 0,630 & & & \\
\hline & $\begin{array}{l}\text { Performans Değerlendirme } \\
\text { Uygulamalarına İlişkin Alg1 }\end{array}$ & 0,404 & 8,801 & 0,000 & & & \\
\hline Bağımlı Değişken & Bağımsız Değişken & 及 & $\mathbf{t}$ & $p$ & $\mathbf{F}$ & $\begin{array}{c}\text { Model } \\
(p)\end{array}$ & $\mathbf{R}^{2}$ \\
\hline \multirow[t]{4}{*}{$\begin{array}{l}\text { Duygusal } \\
\text { Bağlılık(Model 4) }\end{array}$} & Sabit & 1,748 & 10,758 & 0,000 & \multirow{4}{*}{48,410} & \multirow{4}{*}{0,000} & \multirow{4}{*}{0,267} \\
\hline & $\begin{array}{l}\text { Ücret Uygulamalarına İlişkin } \\
\text { Alg1 }\end{array}$ & $\begin{array}{c}- \\
0,097 \\
\end{array}$ & $-2,175$ & 0,030 & & & \\
\hline & $\begin{array}{l}\text { Performans Değerlendirme } \\
\text { Uygulamalarına İlişkin Alg1 }\end{array}$ & 0,311 & 6,417 & 0,000 & & & \\
\hline & İçsel Tatmin & 0,282 & 4,901 & 0,000 & & & \\
\hline
\end{tabular}

Çizelgedeki regresyon modellerine göre sadece çalışanların DB ile ÜUİA düzeyi arasında istatistiksel olarak anlamsız bir ilişki bulunmuştur $(p=0.630>0.05)$. Diğer değişkenler arasındaki ilişkiler anlamlı bulunmuştur $\left(p=0,000<0.05 ; \mathrm{R}^{2}>0\right)$. 
Çizelgedeki 4. regresyon modeline göre ÜUİA, PDUİA' nın DB üzerine etkisinde (Model 1), modele İT'nin eklenmesi ile regresyon modeli anlamlı bulunmuştur ( $\mathrm{F}=48,410 ; p=0,000<0.05)$. Çalışanların ÜUİA düzeyi $\mathrm{DB}$ düzeyini etkilemediğinden aracılıktan söz edilememektedir.

Çizelgedeki 3. regresyon modelinde çalışanların PDUİA düzeyinin DB üzerine etkisi $(\beta=0,404)$, modele İT eklendiğinde (Model 4) azalmaktadır $(\beta=0,311)$. İT'nin PDUİA ile DB arasında aracılık rolüne ilişkin tamamlayıcı olarak Sobel testi sonuçlarına göre PDUİA ile DB arasında İT'nin kısmi ara değişken olduğu anlaşılmaktadır ( $\mathrm{Z}=-3,359 ; p=0,000<0,05)$.

\section{Performans Değerlendirme Ve Ücret Uygulamalarına İlişkin Algı} İle Devam Bağlıı̆̆ı Arasındaki İlişki Ve İçsel İş Tatminin Aracılık Rolüne İlişkin Testler Ve Bulgular

Çizelge 6: Performans Değerlendirme Ve Ücret Uygulamalarına İlişkin Algı İle Devam Bağlılı̆g

Arasındaki İlişki Ve İçsel İş Tatmininin Aracılık Rolüyle İlgili Hiyerarşik Regresyon Modelleri

\begin{tabular}{|c|c|c|c|c|c|c|c|}
\hline Bağımlı Değişken & Bağımsız Değişken & B & $\mathbf{t}$ & $p$ & $\mathbf{F}$ & $\begin{array}{c}\text { Model } \\
(p)\end{array}$ & $\mathbf{R}^{2}$ \\
\hline İçsel Tatmin(Model 1) & Sabit & 1,688 & 14,674 & 0,000 & \multirow{3}{*}{156,432} & \multirow{3}{*}{0,000} & \multirow{3}{*}{0,444} \\
\hline & $\begin{array}{l}\text { Ücret Uygulamalarına } \\
\text { İlişkin Alg1 }\end{array}$ & 0,272 & 7,336 & 0,000 & & & \\
\hline & $\begin{array}{l}\text { Performans Değerlendirme } \\
\text { Uygulamalarına İlişkin Alg1 }\end{array}$ & 0,330 & 8,381 & 0,000 & & & \\
\hline Bağımlı Değişken & Bağımsız Değişken & B & $\mathbf{t}$ & $p$ & $\mathbf{F}$ & $\begin{array}{c}\text { Model } \\
(p)\end{array}$ & $\mathbf{R}^{2}$ \\
\hline \multirow[t]{2}{*}{$\begin{array}{l}\text { Devam } \\
\text { Bağl1lığı(Model 2) }\end{array}$} & Sabit & 1,274 & 7,876 & 0,000 & \multirow[t]{2}{*}{176,854} & \multirow[t]{2}{*}{0,000} & \multirow[t]{2}{*}{0,311} \\
\hline & İçsel Tatmin & 0,577 & 13,299 & 0,000 & & & \\
\hline Bağımlı Değişken & Bağımsız Değişken & B & $\mathbf{t}$ & $p$ & $\mathbf{F}$ & $\begin{array}{c}\text { Model } \\
(p)\end{array}$ & $\mathbf{R}^{2}$ \\
\hline \multirow[t]{3}{*}{$\begin{array}{l}\text { Devam } \\
\text { Bağl1lığı(Model 3) }\end{array}$} & Sabit & 2,018 & 14,448 & 0,000 & \multirow{3}{*}{59,228} & \multirow{3}{*}{0,000} & \multirow{3}{*}{0,230} \\
\hline & $\begin{array}{l}\text { Ücret Uygulamalarına } \\
\text { İlişkin Alg1 }\end{array}$ & 0,324 & 7,195 & 0,000 & & & \\
\hline & $\begin{array}{l}\text { Performans Değerlendirme } \\
\text { Uygulamalarına İlişkin Alg1 }\end{array}$ & 0,103 & 2,151 & 0,032 & & & \\
\hline Bağımlı Değişken & Bağımsız Değişken & B & $\mathbf{t}$ & $p$ & $\mathbf{F}$ & $\begin{array}{c}\text { Model } \\
(p)\end{array}$ & $\mathbf{R}^{2}$ \\
\hline \multirow[t]{4}{*}{$\begin{array}{l}\text { Devam } \\
\text { Bağlılığı(Model 4) }\end{array}$} & Sabit & 1,232 & 7,647 & 0,000 & \multirow{4}{*}{68,447} & \multirow{4}{*}{0,000} & \multirow{4}{*}{0,342} \\
\hline & $\begin{array}{l}\text { Ücret Uygulamalarına } \\
\text { İlişkin Alg1 }\end{array}$ & 0,197 & 4,440 & 0,000 & & & \\
\hline & $\begin{array}{l}\text { Performans Değerlendirme } \\
\text { Uygulamalarına İlişkin Algı }\end{array}$ & $\begin{array}{c}- \\
0,051 \\
\end{array}$ & $-1,059$ & 0,290 & & & \\
\hline & İçsel Tatmin & 0,466 & 8,173 & 0,000 & & & \\
\hline
\end{tabular}

Çizelgedeki 4. regresyon modeline göre ÜUİA, PDUİA, İT ile DEB arasındaki neden sonuç ilişkisini belirlemek üzere yapılan regresyon analizi, istatistiksel olarak anlamlı bulunmuştur $(\mathrm{F}=68,447 ; p=0,000<0.05)$.

Çizelgedeki 3. regresyon modelinde çalışanların ÜUİA düzeyinin DEB üzerine etkisi $(\beta=0,324)$, modele İT dâhil edildiğinde $(\beta=0,197)$ azalmaktadır. İT’nin ÜUİA ile DEB arasında aracılık rolüne ilişkin tamamlayıcı olarak Sobel testi uygulanmıştır. Bu sonuçlara ve ilgili Sobel testi sonuçlarına göre ÜUİA ile DEB 
arasında İT'nin kısmi ara değişken olduğu anlaşılmaktadır $(\mathrm{Z}=-2,884$; $p=0,004<0,05)$.

3. regresyon modelinde çalışanların PDUİA'nın DEB'na etkisi $(\beta=0,103)$, modele İT eklendiğinde ortadan kalkmaktadır $(p=0.290>0.05)$. İT'nin PDUİA ile DEB arasında aracılık rolüne ilişkin tamamlayıcı olarak Sobel testi sonuçlarına göre PDUİA ile DEB arasında İT'nin tam ara değişken olduğu anlaşılmaktadır ( $\mathrm{Z}=$ $3,006 ; p=0,002<0,05)$.

\section{D.Performans Değerlendirme Ve Ücret Uygulamalarına İlişkin Algı İle Duygusal Bağlılık Arasındaki İlişkiler Ve Dışsal İş Tatminin Aracılık Rolüyle İlgili Testler Ve Bulgular}

Çizelge 7: Performans Değerlendirme Ve Ücret Uygulamalarına İlişkin Alg1 İle Duygusal Bağlılık Arasındaki İlişkiler Ve Dışsal İş Tatmininin Aracılık Rolüyle İlgili Hiyerarşik Regresyon Modelleri

\begin{tabular}{|c|c|c|c|c|c|c|c|}
\hline Bağımlı Değişken & Bağımsız Değişken & B & $\mathbf{t}$ & $p$ & $\mathbf{F}$ & $\begin{array}{c}\text { Model } \\
(p)\end{array}$ & $\mathbf{R}^{2}$ \\
\hline $\begin{array}{l}\text { Dişsal } \\
\text { Tatmin(Model 1) }\end{array}$ & Sabit & 0,968 & 10,215 & 0,000 & \multirow{3}{*}{408,979} & \multirow{3}{*}{0,000} & \multirow{3}{*}{0,677} \\
\hline & $\begin{array}{l}\text { Ücret Uygulamalarına } \\
\text { İlişkin Alg1 }\end{array}$ & 0,317 & 10,368 & 0,000 & & & \\
\hline & $\begin{array}{l}\text { Performans } \\
\text { Değerlendirme } \\
\text { Uygulamalarına İlişkin } \\
\text { Alg1 }\end{array}$ & 0,486 & 14,957 & 0,000 & & & \\
\hline Bağımlı Değișken & Bağımsız Değişken & B & $\mathbf{t}$ & $p$ & $\mathbf{F}$ & $\begin{array}{c}\text { Model } \\
(p)\end{array}$ & $\mathbf{R}^{2}$ \\
\hline \multirow[t]{2}{*}{$\begin{array}{l}\text { Duygusal } \\
\text { Bağlılık(Model 2) }\end{array}$} & Sabit & 2,094 & 13,614 & 0,000 & \multirow[t]{2}{*}{89,617} & \multirow[t]{2}{*}{0,000} & \multirow[t]{2}{*}{0,185} \\
\hline & Dişsal Tatmin & 0,395 & 9,467 & 0,000 & & & \\
\hline Bağımlı Değişken & Bağımsız Değişken & B & $\mathbf{t}$ & $p$ & $\mathbf{F}$ & $\begin{array}{c}\text { Model } \\
(p)\end{array}$ & $\mathbf{R}^{2}$ \\
\hline \multirow[t]{3}{*}{$\begin{array}{l}\text { Duygusal } \\
\text { Bağlılık(Model 3) }\end{array}$} & Sabit & 2,224 & 16,581 & 0,000 & \multirow{3}{*}{57,211} & \multirow{3}{*}{0,000} & \multirow{3}{*}{0,224} \\
\hline & $\begin{array}{l}\text { Ücret Uygulamalarına } \\
\text { İlişkin Alg1 }\end{array}$ & $\begin{array}{c}- \\
0,021 \\
\end{array}$ & $-0,482$ & 0,630 & & & \\
\hline & $\begin{array}{l}\text { Performans } \\
\text { Değerlendirme } \\
\text { Uygulamalarına İlişkin } \\
\text { Alg1 }\end{array}$ & 0,404 & 8,801 & 0,000 & & & \\
\hline Bağımlı Değișken & Bağımsız Değişken & B & $\mathbf{t}$ & $p$ & $\mathbf{F}$ & $\begin{array}{l}\text { Model } \\
(p)\end{array}$ & $\mathbf{R}^{2}$ \\
\hline \multirow[t]{4}{*}{$\begin{array}{l}\text { Duygusal } \\
\text { Bağlılık(Model 4) }\end{array}$} & Sabit & 2,022 & 13,517 & 0,000 & \multirow{4}{*}{41,725} & \multirow{4}{*}{0,000} & \multirow{4}{*}{0,239} \\
\hline & $\begin{array}{l}\text { Ücret Uygulamalarına } \\
\text { İlişkin Alg1 }\end{array}$ & $\begin{array}{c}- \\
0,087\end{array}$ & $-1,791$ & 0,074 & & & \\
\hline & $\begin{array}{l}\text { Performans } \\
\text { Değerlendirme } \\
\text { Uygulamalarına İlişkin } \\
\text { Alg1 }\end{array}$ & 0,303 & 5,311 & 0,000 & & & \\
\hline & Dışsal Tatmin & 0,208 & 2,921 & 0,004 & & & \\
\hline
\end{tabular}

Çizelgedeki regresyon modellerine göre sadece çalışanların DB ile ÜUİA düzeyi arasında istatistiksel olarak anlamsız bir ilişki bulunmuştur $(p=0.630>0.05)$. Diğer değişkenler arasındaki ilişkiler anlamlı bulunmuştur $\left(p=0,000<0.05 ; \mathrm{R}^{2}>0\right)$. 
Çizelgedeki 4. regresyon modeline göre ÜUİA, PDUİA, DT ile DB arasında istatistiksel olarak anlamlı bulunmuştur $(\mathrm{F}=41,725 ; p=0,000<0.05)$. Çalışanların ÜUİA düzeyi, DB düzeyini etkilemediğinden aracılıktan söz edilememektedir (Model 3).

2.regresyon modelinde, PDUİA'nın DB üzerine etkisi $(\beta=0,404)$ modele DT'nin eklenmesi ile $(\beta=0,303)$ azalmaktadır. DT'nin PDUİA ile DB arasında aracılık rolüne ilişkin tamamlayıcı olarak Sobel testi sonuçlarına göre PDUİA ile DB arasında DT'nin kısmi ara değişken olduğu anlaşılmaktadır $(Z=-3,456$; $p=0,000<0,05)$.

E. Performans değerlendirme ve ücret uygulamalarına ilişkin algı ile devam bağlılı̆̆ arasındaki ilişkiler ve dışsal iş tatminin aracılık rolüyle ilgili testler ve bulgular

Çizelge 8: Performans Değerlendirme Ve Ücret Uygulamalarına İlişkin Algı İle Devam Bağlılığı Arasındaki İlişkiler Ve Dışsal İş Tatmininin Aracılık Rolüyle İlgili Hiyerarşik Regresyon Modelleri

\begin{tabular}{|c|c|c|c|c|c|c|c|}
\hline Bağımlı Değişken & Bağımsız Değişken & 及 & $\mathbf{t}$ & $p$ & $\mathbf{F}$ & $\begin{array}{c}\text { Model } \\
(p)\end{array}$ & $\mathbf{R}^{2}$ \\
\hline \multirow[t]{3}{*}{ Dişsal Tatmin(Model 1) } & Sabit & 0,968 & 10,215 & 0,000 & \multirow{3}{*}{408,979} & \multirow{3}{*}{0,000} & \multirow{3}{*}{0,677} \\
\hline & $\begin{array}{l}\text { Ücret Uygulamalarına } \\
\text { İlişkin Alg1 }\end{array}$ & 0,317 & 10,368 & 0,000 & & & \\
\hline & $\begin{array}{l}\text { Performans Değerlendirme } \\
\text { Uygulamalarına İlişkin Alg1 }\end{array}$ & 0,486 & 14,957 & 0,000 & & & \\
\hline Bağımlı Değişken & Bağımsız Değişken & B & $\mathbf{t}$ & $p$ & $\mathbf{F}$ & $\begin{array}{c}\text { Model } \\
(p)\end{array}$ & $\mathbf{R}^{2}$ \\
\hline \multirow[t]{2}{*}{$\begin{array}{l}\text { Devam Bağlılığı(Model } \\
\text { 2) }\end{array}$} & Sabit & 1,676 & 10,825 & 0,000 & \multirow{2}{*}{127,642} & \multirow[t]{2}{*}{0,000} & \multirow{2}{*}{0,245} \\
\hline & Dişsal Tatmin & 0,475 & 11,298 & 0,000 & & & \\
\hline Bağımlı Değişken & Bağımsız Değişken & B & $\mathbf{t}$ & $p$ & $\mathbf{F}$ & $\begin{array}{c}\text { Model } \\
(p)\end{array}$ & $\mathbf{R}^{2}$ \\
\hline \multirow[t]{3}{*}{$\begin{array}{l}\text { Devam Bağlılığı(Model } \\
\text { 3) }\end{array}$} & Sabit & 2,018 & 14,448 & 0,000 & \multirow{3}{*}{59,228} & \multirow{3}{*}{0,000} & \multirow{3}{*}{0,230} \\
\hline & $\begin{array}{l}\text { Ücret Uygulamalarına } \\
\text { İlişkin Alg1 }\end{array}$ & 0,324 & 7,195 & 0,000 & & & \\
\hline & $\begin{array}{l}\text { Performans Değerlendirme } \\
\text { Uygulamalarına İlişkin Alg1 }\end{array}$ & 0,103 & 2,151 & 0,032 & & & \\
\hline Bağımlı Değişken & Bağımsız Değișken & 及 & $\mathbf{t}$ & $p$ & $\mathbf{F}$ & $\begin{array}{c}\text { Model } \\
(p)\end{array}$ & $\mathbf{R}^{2}$ \\
\hline \multirow[t]{4}{*}{$\begin{array}{l}\text { Devam Bağlılığ } 1 \text { (Model } \\
\text { 4) }\end{array}$} & Sabit & 1,664 & 10,904 & 0,000 & \multirow{4}{*}{50,411} & \multirow{4}{*}{0,000} & \multirow{4}{*}{0,275} \\
\hline & $\begin{array}{l}\text { Ücret Uygulamalarına } \\
\text { İlişkin Alg1 }\end{array}$ & 0,208 & 4,219 & 0,000 & & & \\
\hline & $\begin{array}{l}\text { Performans Değerlendirme } \\
\text { Uygulamalarına İlişkin Alg1 }\end{array}$ & $-0,074$ & $-1,278$ & 0,202 & & & \\
\hline & Dişsal Tatmin & 0,365 & 5,034 & 0,000 & & & \\
\hline
\end{tabular}

Çizelgedeki 4. regresyon modeline göre ÜUİA, PDUİA, DT ile DEB arasındaki neden sonuç ilişkisini belirlemek üzere yapılan regresyon analizi, istatistiksel olarak anlamlı bulunmuştur $(\mathrm{F}=50,411 ; p=0,000<0.05)$. Model 3'te çalışanların ÜUİA düzeyinin DEB üzerine etkisi $(\beta=0,324)$, modele DT eklendiğinde $(\beta=0,208)$ azalmaktadır. DT'nin ÜUİA ile DEB arasında aracılık rolüne ilişkin tamamlayıcı olarak Sobel testi uygulanmışıı. Bu sonuçlara ve ilgili Sobel testi sonuçlarına göre ÜUİA ile DEB arasında DT'nin kısmi ara değişken olduğu anlaşılmaktadır $(Z=-2,717 ; p=0,006<0,05)$. 3. regresyon modeline göre 
çalışanların PDUİA'nın DEB'na etkisi ( $(=0,103)$, modele DT eklendiğinde ortadan kalkmaktadır $(p=0.202>0.05)$. DT'nin PDUİA ile DEB arasında aracilık rolüne ilişkin tamamlayıcı olarak Sobel testi sonuçlarına göre PDUIA ile DEB arasında DT’nin tam ara değişken olduğu anlaşılmaktadır $(\mathrm{Z}=-3,416 ; p=0,000<0,05)$.

Araştırma sonuçlarına göre ÜUİA ve DB arasındaki ilişkiler ile İT'nin bu ilişkideki aracılık rolüne bağl1 olarak geliştirilen hipotezler reddedilmiş, diğerleri kabul edilmiştir. Kabul ve reddedilen hipotezler şunlardır:

\begin{tabular}{|l|l|l|}
\hline No & HíPOTElge 9:Hipotez sonuçları & SONUÇ \\
\hline H1 & PDUİA, İT'ni olumlu yönde etkiler & KABUL \\
\hline H2 & ÜUİA, İT'ni olumlu yönde etkiler & KABUL \\
\hline H3 & ÜUİA, DT'ni olumlu yönde etkiler & KABUL \\
\hline H4 & PDUİA, DT'ni olumlu yönde etkiler & KABUL \\
\hline H5 & PDUİA, DB'ı olumlu yönde etkiler & KABUL \\
\hline H6 & ÜUİA, DB'1 olumlu yönde etkiler & RET \\
\hline H7 & PDUİA, DEB'nı olumlu yönde etkiler & KABUL \\
\hline H8 & ÜUİA, DEB'nı olumlu yönde etkiler & KABUL \\
\hline H9 & İT, PDUİA ile DB arasında aracıılık rolü üstlenir & KISMİ KABUL \\
\hline H10 & İT, PDUIA ile DEB arasında aracılık rolü üstlenir & KABUL \\
\hline H11 & İT, ÜUİA ile DEB arasında aracılık rolü üstlenir & KISMİ KABUL \\
\hline H12 & DT, PDUİA ile DB arasında arac1lı rolü üstlenir & KISMİ KABUL \\
\hline H13 & DT, PDUİA ile DEB arasında aracılık rolü üstlenir & KABUL \\
\hline H14 & DT, ÜUİA ile DEB arasında aracılık rolü üstlenir & KISMİ KABUL \\
\hline
\end{tabular}

\section{SONUÇ ve ÖNERILER}

Örgüt kaynaklarının doğru bir şekilde kullanımını ve amaçlara ulaşmadaki katkısını ölçmek hususunda araştırmalar geçmişten günümüze devam etmektedir. Performans değerlendirme ve ücret uygulamalarının insan kaynağının katkısını ölçmek açısından öne çıkan uygulamalar olduğunu söylemek mümkündür. $\mathrm{Bu}$ sebeple bu çalışmada örgütsel verimlilik için en önemli rolü üstlenen kaynak olan insanın örgütsel bağlılığının ve iş tatmininin sağlanması için performans değerlendirme ve ücret uygulamalarının etkisinin ortaya çıkartılması hedeflenmiştir. Çalışmanın, birkaç kavram arasındaki ilişkileri incelemesi, insan gücüne dayalı hizmet sektöründen biri olan otel ve konaklama işletmelerinde yapılması ve bu konuda beş yıldızlı otellerde yapılan çalışmaların çok sınırlı olması sebebi ile literatüre önemli bir katkı yapmak amaçlanmıştır.

Araştırma sonuçlarına göre genel olarak performans değerlendirme ve ücret uygulamalarına ilişkin algının hem örgütsel bağlılı̆̆ hem de iş tatminini pozitif etkilediği ve iş tatmininin bu ilişkide ayrıca aracı rolü üstlendiği bulunmuştur. Alt boyutlar açısından incelendiğinde performans ve ücret uygulamaları ile iş tatmini ve alt boyutları olan içsel ve dışsal tatmin arasında pozitif bir ilişki olduğu ancak ücret uygulamalarının duygusal bağlılığı olumlu yönde etkilemediği, dolayısı ile içsel ve dışsal tatminin ücret ile duygusal bağlılık arasında aracılık rolü üstlenmediği bulunmuştur. 
Singh ve Khurana'nın 2016'da yaptıkları araştırmada performans değerlendirmenin duygusal bağll1k üzerinde pozitif bir etkisi olduğu bulmuştur(Singh and Khurana, 2016, 693). Bal, Bozkurt ve Ertemsir yaptıkları çalışmada insan kaynakları uygulamalarından performans değerlendirme ve ücret uygulamaları ile örgütsel bağl1lı arasında olumlu bir ilişki olduğunu, performans uygulamaları ile duygusal bağl1lık arasında pozitif, devam bağl1lığ ile ise negatif bir ilişki olduğunu tespit etmişlerdir (Bal, Bozkurt ve Ertemşir, 2014,1032).

Jeet ve Sayeeduzzafar 2014'te yaptıkları araştırmada performans değerlendirme uygulamalarına ilişkin alg1 ile duygusal bağl1lık arasında pozitif bir ilişki olduğunu bulmuştur (Jeet ve Sayeedzafar, 2014, 72). Bekele ve arkadaşlarının yaptıkları araştırmada performansa ilişkin algının performans sonuçları ve duygusal bağll1ık ile pozitif, işten ayrılma niyeti ile negatif bir ilişkisi olduğu bulunmuştur (Bekele vd., 2014,136).

Ünsal Akbıyık'ın 2012 yılında yaptı̆̆ 1 araştırmada ücret ve performans uygulamalarının örgütsel bağlılığı etkilemediğini tespit etmesine rağmen Hassan ve Mahmood'un 2016'da yaptıkları araştırmada performans değerlendirmenin örgütsel bağl1lık üzerinde pozitif bir etkisi olduğu bulunmuştur (Hassan and Mahmood, 2016, 27). Pangemanan 2015 yılında yaptığı araştırmada performans değerlendirme uygulamalarının örgütsel bağlılı̆̆ını arttırdığını bulmuştur. Ayrıca Lamba ve Choudary'nin (2013) yaptıkları araştırma ile ücret uygulamalarının örgütsel bağlılığı arttırdığı bulunmuştur (Pangemanan, 2015,180-181). Singh ve Rana'nın yaptığ bağl1lık ile pozitif bir ilişki içinde olduğu bulunmuştur (Singh ve Rana, 2015, 2964). Neha ve Himansu 2015 yılında yaptıkları çalışma ile performans uygulamalarına ilişkin algının iş tatmini ve örgütsel bağlılığı arttırdığına ilişkin bulgular elde etmişlerdir (Neha, Himansu, 2015, 102). Ahmad, Iqbal, Javed ve Hamad'ın 2014 yılında yaptıkları çalışmada performansın iş tatmini üzerinde pozitif bir etkisi olduğu bulunmuştur (Ahmad ve diğerleri, 2014, 84). Dolayısıyla çeşitli araştırmacıların elde ettiği bulgular göz önünde bulundurulduğunda bu çalı̧̧ma ile literatürde elde edilen bulguların genel olarak birbirini desteklediğini söylemek mümkündür.

Araştırma sonuçlarına göre; Başarı ve ödüllendirmede adil bir sistemin varlığının, çalışanların iş tatminini pozitif yönde etkilediği bu çalışma ile teyit edilmiştir. $\mathrm{Bu}$ açıdan iş tatmini için performansa dayalı bir ücret sisteminin uygulanması gerekliliği ortaya çıkmaktadır. Duygusal bağlılığın kalpten bağl1lık olduğu ve ücret ile bir ilgisinin olmadığı düşünülürse elde edilen sonucun doğal bir sonuç olduğunu söylemek mümkündür. Örgütlerde arzu edilen bağl1lık türü olan duygusal bağl1lığı oluşturmak için ücretten çok, güven veren liderlik, adil sistemler, uygun çalışma ortamı ve arkadaşlıklar gibi hususların temin edilmesi gerekmektedir. Örgütler için herhangi bir maliyet ve yatırım gerektirmeyen manevi unsurların tesis edilmesi, verimlilik ve etkinliği arttıracaktır. Bu anlamda çalışma bulgularında elde edilen duygusal bağlılık ile ücret uygulamalarının bir ilgisinin olmaması, konaklama işletmelerinin hedeflerine ulaşmaları için öncelikle insan odaklı bir yönetim tarzını benimsemeleri gerektiği ve bu hususta yapılan çalışmaların ücrette yapılacak 
iyileştirmelerden çok daha değerli sonuçlar elde edilmesini sağlayacağını söylemek mümkündür.

$\mathrm{Bu}$ araştırma, Türkiye'nin önemli turizm merkezlerinden ve kalabalık şehirlerinden birisi olan İstanbul'daki beş yıldızlı otellerde yapılmıştır. Bu konularda çalışan diğer araştırmacılar; aynı sektörde faaliyet gösteren ve performans sistemi uygulayan farklı kategorideki ( 3 ve 4 yıldızlı) oteller üzerinde veya farklı turizm bölgelerindeki oteller üzerinde yapması literatüre önemli katkılar sağlayacaktır. Ayrıca farklı sektör çalışanları üzerinde de yapılması performans ve ücret uygulamalarının örgütsel bağll1ık ve iş tatmini üzerinde her sektördeki çalışanlar üzerinde aynı etkiye sahip olup olmadığını tespiti açısından önemlidir.

Çalışanları benzersizlik ve stratejik katkı açısından ele aldığımızda, örgütler için önemli olan kritik pozisyondaki kişilerin tatmini ve bağlılıkları öne çıkan bir husustur. Bu açıdan özellikle stratejik insan kaynaklarını uygulayan örgütlerdeki kritik pozisyondaki çalışanlar üzerinde bu araştırmanın yapılması önerilebilir. Kritik çalışanlar, günümüz güncel kavramlarından olan yetenek yönetiminin de önemli bir unsurudur. Bu sebeple bu araştırmalardan elde edilecek bulgular, yetenek yönetimi stratejilerinin belirlemesinde de yol gösterici olacaktır. Performans ve ücret uygulamalarının yanında diğer insan kaynakları uygulamalarının örgütsel bağlılık ve iş tatmini ile ilişkisi de araştırmak literatüre önemli katkılar sağlayabilecektir.

\section{KAYNAKÇA}

Adeoye A. O. ve Fields Z. (2014). "Compensation Management And Employee Job Satisfaction: A Case Of Nigeria”, Journal of Social Science, V:41(3), pp:345-352. https://www.arcjournals.org/pdfs/ijmsr/v2-i9/13.pdf

Akbıyık B. S. (2012). "İnsan Kaynakları Yönetimi Uygulamalarının Örgüte Bağlılığa Katkısında Çalışma Şekillerinin Rolü: Konaklama İşletmelerinde Bir Araştırma", (Yayınlanmamış Doktora Tezi), İstanbul Üniversitesi, Sosyal Bilimler Enstitüsü, İstanbul.

Akgöz E. ve Aracı Ü.(2018). "İş̧ören İlişkilerinde Yaşanan Sorunların İnsan Kaynakları Yöneticilerinin Bakış Açısından Değerlendirilmesi”, Journal of Tourism and Gastronomy Studies, 6/2, 178-193. DOI: 10.21325/jotags.2018.208

Ali S. B., Mahdi A. ve Malihe J. (2012). "The Effect Of Employees Performance Appraisal Procedure On Their Intrinsic Motivation", International Journal Of Academic Research In Business And Social Sciences, V: 2, No: 12, December, pp: 161-168. http://www.hrmars.com/admin/pics/1369.pdf

Alvi M., Surani M. ve Hirani S. (2013). "The Effect Of Performance Evaluation On Employee's Job Satisfaction In Pakistan, International Airlines Corporation" MPRA Paper No: 46415, Iqra University, pp: 1-30. https://mpra.ub.uni-muenchen.de/64931/1/MPRA_paper_46415.pdf

Armstrong M. (2006). Handbook Of Human Resource Management Practice, UK:Kogan Page.

Armstrong M. (2009). Armstrong's Handbook Of Performance Management, UK:Kogan Page.

Arshad M. A., Masood M. T. ve Amin G. (2013). "Effects Of Performance Appraisal Politics On Job Satisfaction, Turnover Intention And Loyalty To Supervisor", International Review of Management And Business Research, V:2, Issue:3, September, pp:653-673. http://www.irmbrjournal.com/papers/1379412617.pdf

Axson D.A.J.(2010). Best practices in Planning and Performance Management, Third Edition, New Jersey:John Wiley \&Sons.

Bal Y., Bozkurt S. ve Ertemsir E. (2014). "Determining The Influence Of HRM Practices On Increasing Organizational Commitment: An Empirical Research From Turkey", Human Capital Without Borders, Knowledge and Learning For Quality Of Life, 25-27 June, pp:1025-1033. http://www.toknowpress.net/ISBN/978-961-6914-09-3/papers/ML14674.pdf 
Baron, R. M., ve Kenny, D.A., (1986), "The Moderator-Mediator Variable Distinction İn Social Psychological Research: Conceptual, Strategic, And Statistical Considerations”, Journal Of Personality And Social Psychology, 51, ss: 1173-1182. http://psycnet.apa.org/buy/198713085-001.

Bekele A.Z., Shigutu A.D. ve Tensay A.T. (2014). "The Effect Of Employees Perception Of Performance Appraisal On Their Work Outcomes", International Journal Of Management And Commerce Innovations, $\mathrm{V}: 2 \quad \mathrm{~N}: 1, \quad \mathrm{pp}: 136-173$. http://www.researchpublish.com/download.php?file=The\%20Effect $\% 20$ of\%20Employees $\% 20$ Perception\%20-452.pdf\&act=book

Benligiray S. (2016). Insan Kaynakları Yönetimi, Ankara:Nisan.

Bhosale U. ve Kumar K. P. (2015) "Performance Management System And Organizational Commitment”, Pezzottaite Journals, V:4, N:2, April-June, pp:17281731.http://pezzottaitejournals.net/pezzottaite/images/ISSUES/ V4N2/ IJOBMPV4N208.pdf

Bingöl D. (2016). İnsan Kaynakları Yönetimi, İstanbul:Beta.

Cooper L. M. (2011). "Human Resources Management Practices, Job Satisfaction And Organizational Performance In A Public Social Services Agency", (Yayınlanmamış Doktora Tezi), University Of La Verne, College Of Business And Public Management, California.

Çetin C., Elmalı E., Arslan M.L. (2017). İnsan Kaynakları Yönetimi, İstanbul:Beta.

Darehzereski M. (2013). "Effects Of Performance Appraisal Quality On Job Satisfaction In Multinational Companies In Malaysia", International Journal Of Enterprise Computing And Business Systems, V: 2 İssue: 1 January, pp: 1-18. http://www.ijecbs.com/January2013/5.pdf

Deepa E. ve Kuppusamy S. (2014). "Impact Of Performance Appraisal System On Job Satisfaction, Employee Engagement, Organizational Citizenship Behavior And Productivity", Indian Journal Of Applied Research, V: 4, Issue: 2, February, pp: 4-6. https://www.worldwidejournals.com/indian-journal-of-applied-research(IJAR)/file.php?val=February_2014_1392373752_d5a23_55.pdf

Delpo A. (2007). The Performance Appraisal Handbook, USA:Nolo.

Demirel Y. ve Akça B. (2008). "İ̧e Bağlı Stresin Duygusal Bağlılık Üzerine Etkisi: Sağlık Sektörü Çalışanlarına Yönelik Bir Araştırma”, İstanbul Üniversitesi İletişim Fakültesi Dergisi, pp: 43-55. http://dergipark.gov.tr/download/article-file/212185

Dolgun U.(2012), İnsan Kaynakları Yönetimi, Ekin Basım Yayın, Bursa.

Ekmekçi Ö.(2018). "Türk Bankacılık Sektöründe İnsan Kaynakları Uygulamaları Üzerine Nitel Bir Araştırma", Işsletme Araştırmaları Dergisi, 10/2, pp:684-719. DOI: 10.20491/isarder.2018.451.

Erel G. ve Yalçın M. (2014), İletişimci Gözü ile İnsan Kaynakları Yönetimi, İstanbul:Mediacat Kitaplar1.

Eren H. ve Bal M. (2015). "Hemşirelikte Örgütsel Bağlılık”, Sağlık ve Hemşirelik Yönetimi Dergisi, Say1: 1, Cilt: 2 ss: 44-50. doi:10.5222/SHYD.2015.044

Ergeneli A., İlsev A., Camgöz S., Güler B., Karalar P., Ekmekçi Ö., Özgödek D.,Özgödek M.,Odabaş1 N. ve Borluk N. (2016). İnsan Kaynakları Yönetimi, 2. Bask1, Ankara:Nobel Akademik.

Tucker-Lively F.L., 2014, The Relationship Between Human Resource Management Practices And Turnover Intentions Of Mid Level Administrators, Yayınlanmamış Doktora Tezi, Mercer University, Atlanta.

Gupta A. ve Upadhyay D. (2012). "Impact Of Effectiveness Of Performance Mangement System On Employee Satisfaction And Commitment”, International Journal Of Management, IT And Engineering, V:2, Issue:7, July,pp:96-106. https://pdfs.semanticscholar.org/f286/6c4c45469abb8494547585a5c472ddb3ba9f.pdf

Güney S. (2015). Insan Kaynakları Yönetimi, 2. Basım, Ankara:Nobel Akademik.

Gürbüz G., Kumkale İ. ve Oğuzhan A. (2013). "Bankacılık Sektöründe Personel Güçlendirme Uygulamalarının Örgütsel Bağlılığa Etkisi: Trakya Bölgesi Bankalarında Araştırma”, 
Mehmet Seliim Düzgüm \& Akın Maşrap/Performans Değerlendirme Ve Ücret Uygulamalarına İlişkin Algının İş Tatmini Ve Örgütsel Bă̆lılığa Etkisi: Bir Uygulama

International Conference On Eurasian Economies, 2 Session 7C. pp: 791-800. http://avekon.org/papers/767.pdf

Gürbüz S. (2011). "Stratejik İnsan Kaynakları Yönetiminin Örgütsel Bağlılığa ve İş Tatminine Etkisi: İnsan Kaynakları Yöneticileri Üzerinde Bir Araştırma", Atatürk Üniversitesi Sosyal Bilimler Enstitüsü Dergisi, 15(2), P:397-418. http://edergi.atauni.edu.tr/ataunisosbil/article/view/1020007667/1020006831

Hassan S. ve Mahmood B. (2016). "Relationship Between HRM Practices And Organizational Commitment Of Employees: An Empirical Study Of Textile Sector In Pakistan", International Journal Of Academic Research In Accounting, Finance And Management Sciences, V: 6 N: 1, pp: 23-28. DOI: 10.6007/IJARAFMS/v6-i1/1952

Huselid M. (1995). "The Impact Of Human Resource Management Practices On Turnover, Productivity And Corporate Financial Performance”, Academy Of Management Journal, $\begin{array}{lllll}\text { Vol: } & 38, & \text { No: } & 3, & \text { pp: }\end{array}$ http://www.markhuselid.com/pdfs/articles/1995_AMJ_HPWS_Paper.pdf

Iqbal N., Ahmad N., Haider Z., Batool Y. ve Ain Q. (2013). "Impact Of Performance Appraisal On Employee's Performance Involving The Moderating Role Of Motivation", Arabian Journal Of Business And Management Review, V:3, No:1,August,pp:3756.https://www.arabianjbmr.com/pdfs/OM_VOL_3_

(1)/4.pdf

Javed M., Balouch R. ve Hassan F. (2014). "Determinants Of Job Satisfaction And Its Impact On Employee Performance And Turnover Intentions", International Journal Of Learning \& Development, V: 4 N: 2, pp: 120-140. Doi:10.5296/ ijld.v4i2.6094

Jeet V., Sayeeduzzafar, (2014). "A Study Of Human Resources Management Practices And Organizational Commitment In Self Financed Professional Institutions", International Journal Of Advance Research In Computer Science And Management Studies, V: 2, Issue 1, January, pp: 69-73.

Meyer J. and Allen N.J.(1991). "A Three Component Conceptualization of Organizational Commitment", Human Resource Management Review, Vol: 1, ss.61-89, https://doi.org/10.1016/1053-4822(91)90011-Z

Kaliannan M. ve Adjovu S. N. (2015). "Effective Employee Engagement And Organizational Success: A Case Study", Global Conference On Business\& Social Science, GCBSS 201415th \& 16th December, Kuala Lumpur, Procedia-Social And Behavioral Science, pp:161168. doi: 10.1016/j.sbspro.2015.01.350

Karcıoğlu F., Çelik Ü. H., (2012), "Mobbing (Yıldırma) ve Örgütsel Bağlılığa Etkisi”, Atatürk Universitesi IIBFF Dergisi, Cilt: 26, Say1:1, ss: $59-75$. http://dergipark.gov.tr/download/article-file/30274

Karimi R., Malik İ. ve Hussain S. (2011). "Examining The Relationship Of Performance Appraisal System And Employee Satisfaction”, International Journal Of Business And Social Science, V: $\quad 2, \quad \mathrm{~N}: \quad 22, \quad$ December, $\quad \mathrm{P}: \quad 243-247$. http://www.ijbssnet.com/journals/Vol_2_No_22_December_2011/28.pdf

Kaymaz K. (2010). Ücret Yönetimi-Beceri Bazlı Ücretleme Sistemi, Bursa:Dora.

Kitchin D.(2010). Introduction to Organisational Behaviour for Managers and Engineers, First Edition, UK: ELsevier Ltd.

Köroğlu Ö., (2012), "İçsel ve Dışsal İş Doyum Düzeyleri ile Genel İş Doyum Düzeyi Arasındaki İlişkinin Belirlenmesi: Turist Rehberleri Üzerinde Bir Araştırma”, Doğuş Ünv. Dergisi, 13 (2), ss: 275-289. https://core.ac.uk/download/pdf/47254068.pdf

Köse, E. (2017). "Yöneticilerin Karar Verme Yetkinliğinin Yönetsel Performans Üzerindeki Etkileri", (Yayınlanmamış Doktora Tezi), İstanbul Ticaret Üniversitesi Sosyal Bilimler Enstitüsü, İstanbul.

Kumari N. (2013). "Impact Of Perceived Fairness Of Performance Appraisal On Employee Performance", International Review Of Basic And Applied Science, V:1, Issue:4, pp:116128. http://irbas.academyirmbr.com/papers/1376457097.pdf 
Küçüközkan Y. (2015). “Örgütsel Bağl1lık ile Cinsiyet Arasındaki İlişki: Hastanelerde Çalışan Sağlık Personeli Üzerinde Bir Araştırma", Uluslararası Akademik Yönetim Dergisi, Güz, Cilt: 1, S: 1, pp: 14-37. https://mpra.ub.uni-muenchen.de/62746/1/MPRA_paper_62746.pdf

Lira M. (2014). "Satisfaction With The Performance Appraisal System In The Portuguese Public Sector: The Importance Of Perceptions Of Justice And Accuracy", Tekhne-Review Of Applied Management Studies, 12, pp: 30-37. DOI: 10.1016/j.tekhne.2015.01.005

Macey H. W., Schneider B., Barbera K. ve Young S. (2009). Employee Engagement-Tools For Analysis, Practice and Competitive Advantage, UK: Wiley-Blackwell.

Mcshane S. L. ve Glinow M. A. V. (Çev. Ed. Günsel A., Bozkurt S.) (2016). Örgütsel Davranış, Ankara: Nobel Akademik.

Muguongo M., Muguna T. ve Muriithi D. (2015). "Effects Of Compensation On Job Satisfaction Among Secondary School Teachers In Maara Sub-County Of Tharaka Nithi County", Kenya Journal Of Human Resource Management, V: 3 (6), pp: 47-59. doi: 10.11648/j.jhrm.20150306.11

Mullins L. J. (2010). Management and Organisational Behaviour, Ninth edition, England:Prentice Hall.

Munjuri M. ve K'obonyo P. (2015). "Human Capital, Employee Empowerment And Performance Of Commercial Banks And Insurance Firms In Kenya", International Journal Of Arts And Commerce, V:4 N:6, pp:163181.http://www.ijac.org.uk/images/frontImages/gallery/Vol._4_No._6/17._163-181.pdf

Naji A, Mansoour J. ve Leclerc A. (2015). "Performance Appraisal System And Employee Satisfaction: The Role Of Trust Towards Supervisors", Journal Of Human Resources Management And Labor Studies, V: 3 N: 1, pp: 40-53. DOI: 10.15640/jhrmls.v3n1a3

Nazir T., Khan S., Shah S. ve Zaman K. (2013). "Impact Of Rewards And Compensation On Job Satisfaction: Public And Private Universities Of UK", Middle-East Journal Of Scientific Research, 14 (3), pp: 394-403. DOI: 10.5829/idosi.mejsr.2013.14.3.314

Neha S. ve Himanshu R. (2015). "Impact Of Performance Appraisal On Organizational Commitment And Job Satisfaction", International Journal Of Engineering And Management Sciences, $\mathrm{V}: \quad 6 \quad(2), \quad \mathrm{pp}: \quad 95-104 . \quad \mathrm{http} / / /$ scienceandnature.org/IJEMS-Vol6(2)Jan2015/IJEMS\%20Vol6(2)-10.pdf

Özer M. A., Sökmen A, Akçakaya M. ve Özyadın M. M. (2017). İnsan Kaynakları Yönetimi, Ankara:Gazi.

Özkalp E., Keser A., Acar P., Varoğlu D. ve Kırel Ç. (2013). Organizasyonlarda Davranış, 1. Bask1, Eskişehir:Anadolu Üniversitesi.

Pangemanan M. (2015). "The Impact Of Staffing, Training And Development, Performance Management On Organizational Commitment at PT. BTN (Persero) TBK. MANADO", Jurnal EMBA, $\quad \mathrm{V}: \quad 3 \quad$ No: $\quad 1, \quad$ pp: $173-182$. https://ejournal.unsrat.ac.id/index.php/emba/article/view/6677/6196

Prabusankar R. (2015). "Impact Of Human Resource Management Practices On Organizational Commitment In Small Scale Industries In Coimbatore District", International Journal of Business And Administration Research Review, V:2, Issue:11, July-September, pp:164-168. http://www.ijbarr.com/downloads/0610201531.pdf

Rizal M., Idrus S., Djumahir ve Mintarti R. (2014). "Effect Of Compensation On Motivation, Organizational Commitment And Employee Performance (Studies At Local Revenue Management In Kendari (City)", International Journal Of Business And Management Invention, V.3 Issue 2 pp: 64-79. http://www.ijbmi.org/papers/Vol(3)2/Version1/I0321064079.pdf

Robbins, SP \& Judge, T. (Çev. Ed. Erdem, İ), (2015), Örgütsel Davranış, Ankara:Nobel Akademik. Sabuncuoğlu Z. (2013). İnsan Kaynakları Yönetimi, İstanbul: Beta.

Sacchetti S., Tortia E. C. ve Arceiz F. J. L. (2016). "Human Reources Management Practices And Organizational Performance. The Mediator Role Of Immaterial Satisfaction In Italian Social Cooperatives", DTECONZ Faculted De Economia Y Empresa, Universidad De Zaragoza, pp: 1-30. http://oro.open.ac.uk/46063/1/WP-1.pdf 
Mehmet Seliim Düzgüm \& Akın Maşrap/Performans Değerlendirme Ve Ücret Uygulamalarına İlişkin Algının İş Tatmini Ve Örgütsel Bă̆lılığa Etkisi: Bir Uygulama

Sadullah Ö., Uyargil C., Acar C., Özçelik O., Dündar G., Ataay İ., Adal Z. ve Tüzüner L. (2015). Insan Kaynakları Yönetimi, 7. Bask1, İstanbul: Beta.

Salisu J., Chinyio E. ve Suresh S. (2015). "The Impact Of Compensation On The Job Satisfaction Of Public Sector Construction Workers Of Jigawa State Of Nigeria", The Business And Management Review, V:6, N:4, P:282296.http://www.abrmr.com/myfile/conference_proceedings/Con_Pro_66154/2015iacp47.p df

Salleh M., Amin A., Mude S. ve Abdulhalim M. A. S. (2013). "Fairness Of Performance Appraisal And Organizational Commitment”, Asian Social Science, V: 9, No: 2, pp: 121-128. doi:10.5539/ass.v9n2p121

Sanyal M. K. ve Biswas S. B. (2014). "Employee Motivation From Performance Appraisal Implications: Test Of A Theory In The Software Industry In West Bengal (India)", Porcedia Economics And Finance, V: 11, pp: 182-196. doi: 10.1016/S2212-5671(14)00187-7

Scheible A. C. F. ve Bastos A. V. B. (2013). "An Examination Of Human Resource Management Practices Influence On Organizational Commitment And Entrenchment”, BAR, Rio de Janeiro, V: 10, N: 1, pp. 57-76. http://www.scielo.br/pdf/bar/v10n1/aop1012.pdf

Selvarasu A. ve Sastry S. K. (2014). "A Study Of Impact On Performance Appraisal On Employee Engagement In An Organization”, International Journal Of Managerial Studies And Research, V: 2, Issue: 11, December, pp: 10-22. https://www.arcjournals.org/pdfs/ijmsr/v2i11/3.pdf

Shields J. (2007). Managing Employee Performance And Reward, UK:Cambridge University.

Sial M. A., Jilani S., Imran R. ve Zaheer A. (2011). "Effect Of Human Resource Practices On Organizational Commitment In Pakistani Universities", World Applied Science Journal, $\mathrm{V}: 15(6)$, https://pdfs.semanticscholar.org/0f19/4838ad09cbe735eba84e5ddf5af0b29bb534.pdf

Sims R. (2002). Organizational Success Through Effective Human Resources Management, USA:Quorum.

Singh P. ve Rana S. (2015). "The Impact Of Performance Appraisal On Organizational Commitment Of Bank Employees", International Journal Of Science And Research, V:4, Issue:4, pp:2964-2967. https://www.ijsr.net/archive/v4i4/SUB153899.pdf

Singh S. P. ve Rana S. (2014). "Impact Of Performance Appraisal On The Motivation Of Teachers Of Professional Institutions In Dehradun City”, IFRSA Business Review, V:4, Issue:1, March, pp:127-130 https://www.researchgate.net/profile/S_Singh11/publication/261070435_Impact_of_Perfo rmance_appraisal_on_the_Motivation_of_Teachers_of_Professional_Institutions/links/00 b4953327f99df1dc000000/Impact-of-Performance-appraisal-on-the-Motivation-ofTeachers-of-Professional-Institutions.pdf

Singh S. ve Khurana K. (2016). "Human Resource Management Practices And Organizational Commitment In Self-Financing Institutions Of Delhi \& NCR Region”, XVII Annual International Seminar Proceedings, January, pp:693-702. http://www.internationalseminar.org/XVII_AIS/TS5A_PDF/5.Supreet\%20Singh.pdf

Singh S.P., Wahla R., 2015, Awareness And Perceived Significance Of Performance Appraisal In Indian Pharmaceutical Industry, International Journal of Business And Management, V:3 Issue:4, April, P:323-328. http://www.theijbm.com/wp-content/uploads/2015/05/35.BM1504-062_update.pdf

Sirca N., Babnik K. ve Breznik K. (2012). "The Relationship Between Human Resource Development System And Job Satisfaction”, Management Knowledge And Learning, International Conference, 2012, pp:977-987. http://issbs.si/press/ISBN/978-961-6813-105/papers/ML12_212.pdf

Smeenk S. G. A, Eisinga R. N., Teelken J. C. ve Doorewaard J. A. M. (2006). “The Effects Of HRM Practices And Antecedents On Organizational Commitment Among University Employees", International Journal Of Human Resources Management, V: 17 (12) December, pp: 2035-2054. DOI: 10.1080/09585190600965449 
Şendoğdu A. (2014). Bankalarda İnsan Kaynakları Yönetimi-İse Alım ve Performans Değerlendirme, 1. Basım, Ankara: Nobel Akademik.

Tekingündüz S. ve Tengilimoğlu D. (2013). "Hastane Çalışanlarının İş Tatmini, Örgütsel Bağlılık ve Örgütsel Güven Düzeylerinin Belirlenmesi”, Sayıştay Dergisi, Sayı:91, Ekim-Aralık, ss:77103. http://apbs.mersin.edu.tr/files/stekingunduz/Publications_008.pdf

Torrington D.,Hall L.,Taylor S.(2008). Human Resources Management, Seventh Edition, England:Pearson Education Limited.

Tuna M. (2016). Insan Kaynakları Yönetimi, Ankara: Detay.

Tuncer M. (2011). "Performans Değerleme Uygulamalarının Otel Çalışanları Üzerindeki Etkileri”, Adlyaman Üniversitesi Sosyal Bilimler Enstitüsü Dergisi, Y11:4, Say1:7, Aralık,S:258-279. http://dergipark.ulakbim.gov.tr/adyusbd/article/view/5000041759

Tüzüner L. (2014), İnsan Kaynakları Faaliyetlerinde Ölçme ve Değerlendirme, Beta Basım, 1. Bask1, İstanbul.

Vasudevan S. (2014). "Perceived Fairness Of Performance Appraisal System And Personal FactorsA Conceptual Debate", AIJRHASS, C:8(1), pp:10-23. http://iasir.net/AIJRHASSpapers/AIJRHASS14-602.pdf

Weiss D.J., Dawis W.R., England G.W., Lofquist L.H.(1967). "Manual For The Minnesota Satisfaction Questionnare", Minnesota Studies in Vocational Rehabilition, Vol:12, University of Minnesota Industrial Relation Center, Minneopolis. http://psycnet.apa.org/record/1968-08111-001.

\section{SUMMARY}

Research on the efficiency of organizational resources has been continuing today. It is possible to say that performance appraisal and compensation applications are prominent applications in measuring the efficiency of human resources. In this study, it was researched whether the effect of performance evaluation and compensation applications on organizational commitment and job satisfaction, and whether job satisfaction has a mediating role between performance and compensation applications and organizational commitment. In the literature, the number of comprehensive studies that analyze performance appraisal and compensation practices on organizational commitment and job satisfaction are very limited. The aim of the study was to make a significant contribution to the literature because the study of the relationship between several concepts together, the establishment of one of the services sector based on human power and the work done in five star hotels in Turkey is limited.

The research was conducted on 5-star hotels operating in Istanbul. According to May 2016 data from the Ministry of Culture and Tourism database, the number of 5-star hotels in Istanbul is 86 . Individual phone calls and interviews were conducted with this hotel to determine if the correct measurement was made and in particular if performance practices existed. 440 questionnaires were collected back and 391 questionnaires were found significant for statistical analysis. The obtained data were subjected to t-test, one-way ANOVA test and the Scheffe test as a post hoc analysis. A Pearson correlation analysis was applied among the variables of the study. In the study, hierarchical regression models were also applied and a test developed by Sobel was used to determine the mediating effect after hierarchical regression models. The relationship between job satisfaction and organizational commitment subscales of performance and compensation practices in the research is also examined. In this study, it was found 
that the perceptions about performance and compensation applications positively affect organizational commitment and job satisfaction, and that job satisfaction also has an intermediary role in this relation. When examined from the perspective of sub-dimensions, there is a positive relationship between performance and compensation practices with job satisfaction and sub-dimensions but found that compensation practices did not affect emotional commitment positively, so that internal and external satisfaction did not play a mediating role between compensation and emotional commitment. 